\title{
ALGUNOS EJEMPLOS AISLADOS DE LA PRESENCIA DE PINTURA BARROCA ESPAÑOLA Y FLAMENCA EN GALICIA
}

\author{
Por \\ JUAN M. MONTERROSO MONTERO
}

\section{I.- INTRODUCCIÓN}

Galicia no es ajena, durante el siglo XVII y, como consecuencia inmediata de éste, en el siglo XVIII, al interés progresivo hacia la pintura que se produce en el resto de España. Aunque todavía falta un estudio global sobre el «coleccionismo» o los «aficionados al arte de la pintura» en Galicia ${ }^{1}$, ciertos rasgos comunes permiten plantear la existencia de ese nuevo tipo de coleccionista que se ha definido como barroco ${ }^{2}$.

De este modo, si bien se desconocen los bienes artísticos que hidalgos, artistas, nobles y eclesiásticos atesoraban en los gabinetes de sus casas, es posible descubrir a través de algunas de las obras que se conservan en catedrales, monasterios e iglesias, una tendencia a donar y adornar dichos espacios con pinturas de tema eminentemente religioso que, en algunos casos, no proceden de talleres locales.

\footnotetext{
' Existen, sin embargo, aproximaciones puntuales a personajes concretos. Véase FOLGAR DE LA CALLE, M ${ }^{\mathrm{a}}$.C.: «Un inventario de bienes de Fernando de Casas», Cuadernos de Estudios Gallegos, XXXIII, 98, (1982), pp. 535-547; FERNANDEZ GASALLA, L.: «Las obras de Guido Reni en la colección del arzobispo de Santiago Don Pedro Carrillo (1656-1667)», Boletín del Seminario de Arte y Arqueología, LVIII, (1992), pp. 431-435.

${ }^{2}$ MORAN, M., CHECA, F.: El coleccionismo en España. Madrid, 1985, pp. 231-249.

"CUADERNOS DE eSTUDIOS GALLEGOS", Tomo XLIII, Fascículo 108, Santiago 1996.
} 
Al igual que en el resto de la Península, el gusto de la clientela se divide en dos polos diferentes: la pintura italiana y la flamenca. En el caso gallego, habría que añadir la castellana, tanto salmantina, vallisoletana o madrileña.

Estas obras «importadas» venían a cubrir una carencia fundamental en el panorama gallego: la ausencia de maestros de calidad que pudiesen redimir a la pintura y al oficio de pintor de su condición $\operatorname{artesanal}^{3} \mathrm{y}$, a la vez, satisfacer los gustos y exigencias de la clientela gallega que buscaba fuera, aquello que no encontraba dentro.

En este capítulo de pinturas «importadas» se podría enumerar un gran número. Muchas de ellas se ha dado a conocer de un modo aislado: es el caso de la Virgen de Nuestra Señora del Socorro del monasterio de San Martín Pinario de Santiago ${ }^{4}$, obra de Claudio Coello, de la Inmaculada Concepción de la catedral de Ourense, de Baltasar de Castrejón ${ }^{5}$, de los lienzos de los Peti, también en la basílica orensa-

\footnotetext{
${ }^{3}$ MONTERROSO MONTERO, J.M.: «La condición social del pintor en la Galicia de los siglos XVII y XVIII», Cuadernos de Estudios Gallegos, XLII, 107, (1995), pp. 371-391.

${ }^{4}$ Cfr. ARRESE, J.L. de: Arte religioso de un pueblo de España. Madrid, 1963, p. 421; ARRESE, J.L. de: El arte, la función y la medalla de honor. Madrid, 1980, p. 421.; CAMON AZNAR, J.: La pintura española del siglo XVII. Summa Artis, 25. Madrid, 1977, p. 482.; FILGUEIRA VALVERDE, J.: Guía de Santiago. La Coruña, 1958, p. 98.; GAYA NUÑO, J.A.: Claudio Coello. Madrid, 1957, pp. 12, 19, 35; GONZALEZ GARCIA, M.A.: «Datos para la historia de Nuestra Señora del Socorro de Santiago de Compostela», Boletín del Seminario Fontán-Sarmiento, 6-7-8, (1980), pp. 16-22; LOPEZ LOPEZ, R.: Guía del peregrino y del turista. Santiago, 1950, p. 162; PAZ CARBALLO, M.. La pintura en las iglesias de Santiago. Santiago, 1958, p. 95; SULLIVAN, E.J.: Claudio Coello y la pintura barroca madrileña. Madrid, 1989, pp. 199-200; MONTERROSO MONTERO, J.M.: «Aproximación al estudio del patrimonio pictórico de San Martín Pinario. (Cuatro ejemplos de los siglos XVII y XVIII)», Compostellanum, en prensa.

${ }^{5}$ Cfr. FERNANDEZ OTERO, J.C., GONZALEZ GARCIA, M.A., GONZALEZ PAZ, J.: Apuntes para el inventario del mobiliario litúrgico de la Diócesis de Ourense. Vigo, 1983, p. 195; GUTIERREZ PASTOR, I.: «Antonio de Castrejón como retratista y otras obras de su hijo Baltasar», Anuario del Departamento de Historia y Teoría del Arte, III, (1991), pp. 101-108; PEREZ SANCHEZ, A.E.: Pintura barroca en España, 1600-1750. Madrid, 1992, p. 335; URREA, J.: «Obras de pintores menores madrileños: Baltasar de Castrejón, A. van Pere y P. Ruiz González», Boletín del Seminario de Arte y Arqueología de Valladolid, XL-XLI, (1975), pp. 707-712; URREA, J.: Pintura, en VALDIVIESO, F.,
}

"CUADERNOS DE ESTUDIOS GALLEGOS", Tomo XLIII, Fascículo 108, Santiago 1996. 
na ${ }^{6}$, del cuadro de San Francisco de Asís en oración, atribuido a Zurbarán, de la iglesia conventual de la Madres Capuchinas de A Coruña7. Otras, como las imágenes dedicadas a Nuestra Señora de Guadalupe ${ }^{8}$, los cobres flamencos ${ }^{9} \mathrm{o}$ los retratos, responden a unas condiciones de producción y serialización que tendrán que ser tratadas en otros estudios.

Por esa razón, en este trabajo sólo se recogen aquellos ejemplos inéditos procedentes de diferentes escuelas peninsulares y un ejemplo ya conocido, pero sumamente significativo, de pintura flamenca.

Como elementos en común se han podido constatar ciertos aspectos como: la presencia de obras preferentemente salmantinas, vallisoletanas y madrileñas; su notable calidad frente a las producciones locales, si bien es cierto que en muchos casos se trata de artistas menores dentro del

OTERO, R., URREA, J.: El Barroco y el Rococó, en Historia del Arte Hispánico, IV, Madrid, 1980, pp. 323; YZQUIERDO PERRIN,R., GONZALEZ GARCIA, M.A., HERVELLA VAZQUEZ, J.: La Catedral de Orense. Orense, 1993, p. 141; MONTERROSO MONTERO, J.M.: «La pintrua de los siglos XVII-XVIII», La Catedral de Ourense, en prensa.

${ }^{6}$ Cfr. MONTERROSO MONTERO, J.M.: «Dos cuadros de Simón Peti en la Catedral de Orense. (Los determinantes religiosos activos en la primera mitad del siglo XVIII)», Porta da Aira, 1994.

${ }^{7}$ Cfr. CASTILLO, A. del: Inventario monumental y artístico de Galicia. A Coruña, 1987, p. 259; GARCIA IGLESIAS, J.M.: La pintura religiosa moderna en la archidiócesis compostelana. Santiago de Compostela, 1973, p. 93; GUINARD, P.: Zurbarán et les peintres spagnols de la vie monastique. París, 1960, p. 252, lám. 357; GUINARD, P.: «El «San Francisco» zurbaranesco de La Coruña», Archivo Español de Arte, XXXVII, (1964), pp. 196-197.

${ }^{8}$ Este es uno de los casos más significativos de relación transitiva e influencia mutua en el ámbito del arte. Las imágenes de Nuestra Señora de Guadalupe, devoción mariana fuertemente enraizada en Galicia, llegan en su mayoría desde el otro lado del Atlántico y sirven de modelo a reinterpretaciones locales y polulares.

${ }^{9}$ La existencia de una producción en serie y la comercialización por el resto de Europa de estos cobres, es algo conocido. En el caso gallego, es significativo descubrir que muchas de las cajonerías que amueblan las sacristías de monasterios y catedrales se decoran con este tipo de pintura. Ejemplos sobresalientes son: la cajonería de San Martín Pinario, de la catedral de Santiago o de la Catedral de Mondoñedo.

Al margen quedan aquellos cobres que llegan de un modo aislado. Tal vez los más significativos sean los conservados en la sala capitular de la catedral de Santiago de Compostela, obra de Franz Francken III y atribuidos tradicionalmente a Juan Antonio García de Bouzas. MONTERROSO MONTERO, J.M.: La pintura barroca en Galicia. Santiago de Compostela, 1995, pp. 525-528.

"CUADERNOS DE ESTUDIOS GALLEGOS", Tomo XLIII, Fascículo 108, Santiago 1996. 
ámbito nacional; y su localización en centros episcopales y monásticos, lo que demuestra la estrecha relación entre las obras comentadas y los gustos de los personajes que hacen posible su llegada a Galicia.

\section{ALGUNAS ATRIBUCIONES: LORENZO DE AGUIRRE, DIEGO POLO, BERNARDO DE LA PEÑA, ALONSO DEL ARCO Y LOS PETI}

Asunción de la Virgen. Catedral de Mondoñedo ${ }^{10}$. (Lám. 1) No poseemos noticia alguna sobre este lienzo que aparece firmado en su ángulo inferior izquierdo como Lorenzo d Aguirre ft ano 1618. Según Villaamil, en 1865 se hallaba en el lugar que hoy ocupa, es decir, en la sala capitular, bajo el dosel episcopal ${ }^{11}$. La fecha de su ejecución y el nombre de su autor, totalmente desconocido, permiten suponer que se trata de una obra de procedencia no gallega cuya presencia, dentro del patrimonio catedralicio mindoniense estaría justificada en función de una donación personal promovida por alguno de los señores obispos que ocuparon esta sede. Quizás, este anónimo prelado deba identificarse con fray Rafael Díaz de Cabrera (1618-1630), trinitario madrileño, que había alcanzado el cargo de Provincial de Castilla, León y Navarra, del cual Flórez comenta que «hizo varios donativos ála Fábrica y Sacristía» ${ }^{12}$.

La obra se debe encuadrar dentro de ese primer tercio del siglo XVII, dentro de las fórmulas desarrolladas en los círculos cortesanos madrileños.

La escena se divide en dos partes: la superior, en la que vemos la figura de María que asciende hacia el cielo -con gesto humilde y actitud

\footnotetext{
${ }^{10}$ Autor: Aguirre, Lorenzo de. Cronología: 1618. Soporte: Lienzo. Técnica: Oleo. Estado: Los barnices han oscurecido ligeramente sus colores. Medidas: 138 × $230 \mathrm{cms}$. Localización: MONDOÑEDO. Mondoñedo. Catedral. Sala Capitular. (Mondoñedo). (AYUNTAMIENTO. Localidad. Lugar. Localización concreta. (Arciprestazgo).

${ }^{11}$ Villaamil y Castro comenta que había sido restaurada recientemente, lo cual explicaría la presencia de una capa de barniz tan intensa. VILLAAMIL Y CASTRO, J.: La catedral de Mondoñedo. Su historia y descripción. Sus pinturas murales, accesorios, moviliario, bronces y orfebrería, vestiduras y ropas sagradas. Madrid, 1865, p. 54.

${ }^{12}$ FLOREZ, E.: España Sagrada. Theatro Geographico-Histórico de la Iglesia de España. XVIII. Madrid, Antonio Marín, 1764, pp. 263.
}

"CUADERNOS DE ESTUDIOS GALLEGOS", Tomo XLIII, Fascículo 108, Santiago 1996. 


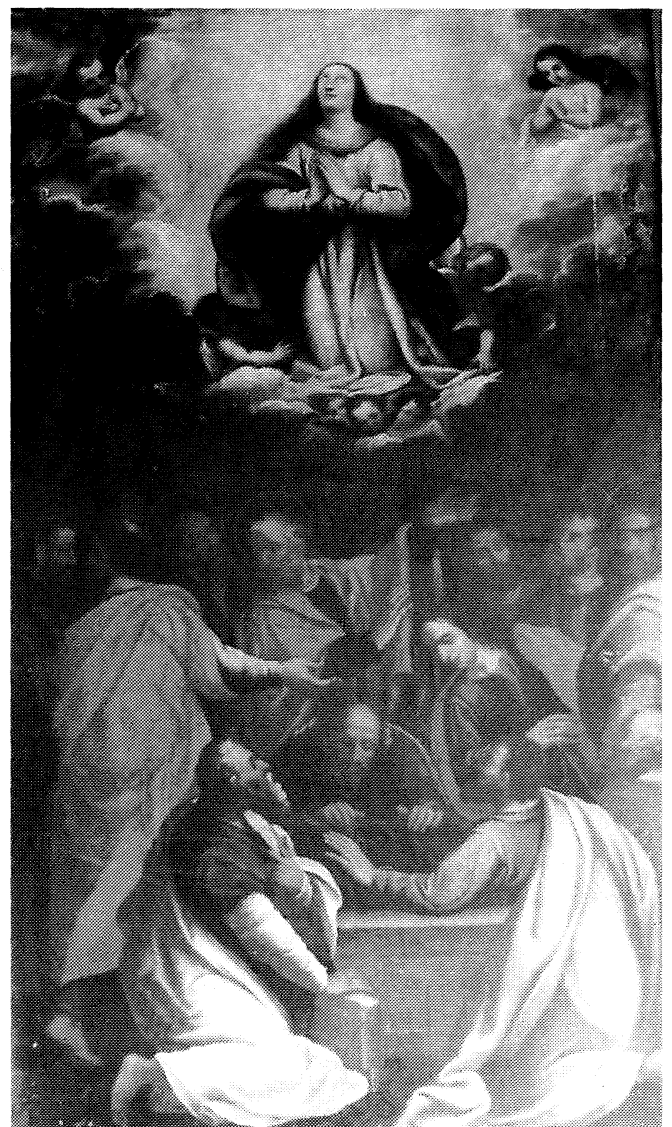

Lámina 1. Asunción de la Virgen. Catedral de Mondoñedo

orante- acompañada por un cortejo de ángeles; y la inferior, en la que se puede observar como los apóstoles se debaten entre la incertidumbre y la sorpresa -unos discuten entre sí, otros miran en el interior del sarcófago vacío y, por último, unos pocos contemplan la ascensión de María ${ }^{13}$.

\footnotetext{
${ }^{13}$ Este esquema narrativo es el reflejo plástico de la Leyenda Dorada cuya tradición se mantuvo, tanto entre artistas como entre los fieles, a pesar de ser apócrifa y contradecir los edictos de Trento. MALE, E.: El Barroco. Arte religioso del siglo XVII. Italia, Francia, España, Flandes. Madrid, 1985, p. 322.

En este sentido es muy interesante el comentario de Interián de Ayala que al referirse a este tema dice lo siguiente: «Y que por la virtud de Dios, resucitase la Soberana Reyna
}

"CUADERNOS DE ESTUDIOS GALLEGOS", Tomo XLIII, Fascículo 108, Santiago 1996. 
Aguirre, junto a un dibujo correcto y trabajado -que no impide que cometa ciertos errores- presenta una composición excesivamente simétrica que se corresponde con el eje trazado por María y el sepulcro -situado de un modo rigurosamente frontal- que le resta agitación y dinamismo a la obra. Su interés se centra ante todo en la luz, cuyos efectos nocturnos, dentro de la más pura tradición veneciano bassanesca, se hacen evidentes en el grupo de apóstoles del segundo término o, en las nubes sobre las que se sitúa la Virgen. Por otra parte, contrasta la actitud estática de María con los gestos dinámicos del grupo de apóstoles, si bien, éstos son un tanto teatrales y rígidos. Asimismo, tanto el grupo de ángeles volantes -cuyo número se ha reducido de forma acusada- como su gama cromática, delatan una herencia veneciana ligada a los modelos introducidos en España por los pintores italianos que en las décadas de 1580 y 1590 vinieron a trabajar a El Escorial ${ }^{14}$.

\footnotetext{
después de tres días, y que así resucitada, fuese llevada sobre los Cielos, y Coros de los Angeles; es una verdad que nadie podrá contradecir... Pero... podría representarse este triunfo de la Virgen, del modo que ya algunos lo han practicado; á saber, pintando á la Sacratíssima Virgen y Madre de Dios, adornada con ricos vestidos, y con un semblante hermossísimo (que de ningún modo se le debe pintar con el semblante viejo; pues fuera de que permaneció siempre Virgen intacta, ya estaba adornada, y revestida con las dotes de la gloria) afianzada en el Hombro de su amado Hijo, conforme lo que leémos en los Cantares (8.5) «¿Quién es esta que sube del desierto, abundando en delicias, y recostada sobre su amado?» y encaminándose á lo más alto de los Cielos, rodeada por todas partes de muchedumbre de Angeles. Pero, por ser común, y freqüente, el pintarla subiendo á los Cielos por mano de Angeles (bien que no necesitaba de este auxilio el cuerpo glorioso, y dotado ya de admirable agilidad), es justo, que también se pinte así, y más conforme á la piedad popular. Subida ya á los Cielos, suelen representárnosla (y con razón) hermossísima; pero, muy modesta, juntas las manos ante el pecho, y recibiendo una corona de oro en su cabeza de manos del Padre Eterno, y de su Hijo, sobre las quales se dexa ver en la acostumbrada forma la paloma...». INTERIAN DE AYALA, J.: Pictor Christianus Eruditus..., op. cit., II, pp. 50-51.

${ }^{14}$ Existen ciertas semejanzas entre esta Asunción y la obra de Angelo Nardi, en especial con la procedente del convento de Bernardas de Alcalá de Henares. Asimismo, es inevitable ponerla en relación con la obra de Federico Zuccaro, realizada en 1587, de El Escorial. ANGULO IÑIGUEZ, D., PEREZ SANCHEZ, A.E.: Pintura madrileña del primer tercio del siglo XVII. Madrid, 1969, pp. 276, láms. 212, núm. 6.
}

"CUADERNOS DE ESTUDIOS GALLEGOS", Tomo XLIII, Fascículo 108, Santiago 1996. 
San Jerónimo. Catedral de Ourense ${ }^{15}$. (Lám. 2) La identidad de Diego Polo (1610?-1655) se ha ido perfilando poco a poco con el paso del tiempo; su personalidad artística y su estilo se han concretado hasta dar una visión coherente y bastante precisa, teniendo en cuenta la parquedad de noticias con que se cuenta, de su figura ${ }^{16}$. Reconocida su filiación escurialense, su formación previa con Lanchares, y el profundo conocimiento de la obra de Tiziano, sobre todo su colorido, el atribuirle el San

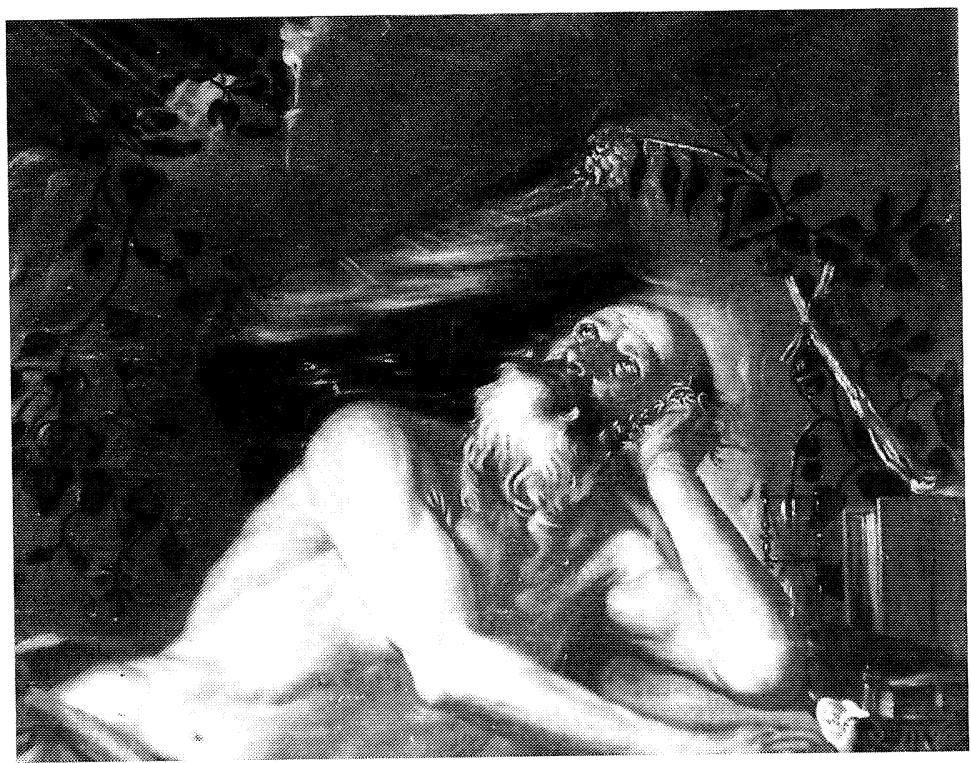

Lámina 2. San Jerónimo. Catedral de Ourense. Detalle

${ }^{15}$ Autor: Diego Polo?. Cronología: Segundo cuarto del siglo XVII. Soporte: Lienzo. Técnica: Oleo. Estado: Bueno aunque presenta algunas pérdidas de pigmentación en la parte inferior de la tela. Medidas: 170 x $120 \mathrm{cms}$. aprox. Localización: OURENSE. Ourense. Catedral. Sacristía. (Ourense).

${ }^{16} \mathrm{Al}$ margen de las citas clásicas que apunta Pérez Sánchez en sus estudios -los escritos de Díaz del Valle, Palomino o Cean Bermúdez-, es este autor el que ha rescatado del olvido la obra de Polo. Véase PEREZ SANCHEZ, A.E.: «Diego Polo», Archivo Español de Arte, (1969), XLII, pp. 43-54; PEREZ SANCHEZ, A.E.: «Presencia de Tiziano en la España del siglo de Oro», Goya, 135, (1976), pp. 156-157; PEREZ SANCHEZ, A.E.: «La obra de Diego Polo, imitador español de Tiziano», en Tiziano e Venezia. Convegno Internazionale di Studi. Venezia, 1979. Venecia, 1980, pp. 351-355; ANGULO IÑIGUEZ, D., PEREZ SANCHEZ, A.E.: La pintura madrileña del segundo tercio del siglo XVIII. Madrid, 1983, 240-252; PEREZ SANCHEZ, A.E.: Pintura Barroca en España, 1600-1750. Madrid, 1992, pp. 246-248.

"CUADERNOS DE ESTUdIOS GALLEGOS", Tomo XLIII, Fascículo 108, Santiago 1996. 
Jerónimo conservado en la sacristía de la catedral de Ourense no es, en ningún caso, improcedente -sobre todo constatando la íntima relación que une a esta obra con el lienzo sobre el mismo tema perteneciente a la Alte Pinakothek de Münich, depositado en el Palacio Schleissheim ${ }^{17}$.

Las dos telas, la de Münich (Lám. 3) y Ourense, responden a un mismo modelo, resultando, incluso, sorprendente tal semejanza. La gallega representa al Santo Eremita de cuerpo entero, semidesnudo -cubierto por un amplio paño rojo con destellos dorados-, inmerso en un paisaje agreste y umbrío, cuya aspereza queda patente tanto por el perfil aristado y

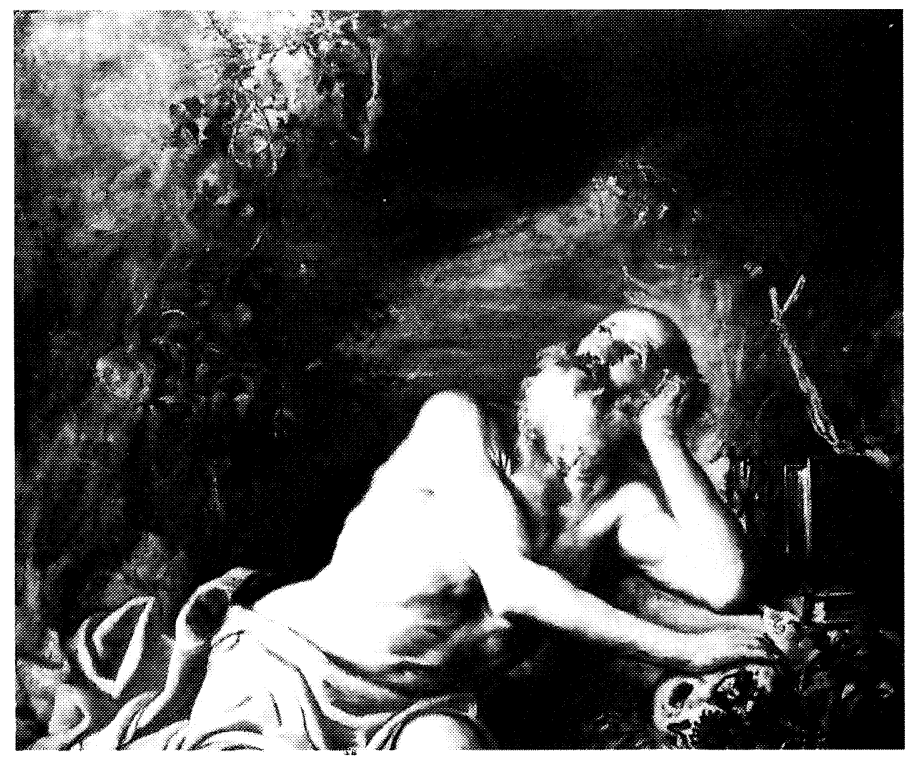

Lámina 3. San Jerónimo. Alte Pinakothek. Münich.

\footnotetext{
${ }^{17}$ Dicho cuadro, atribuido por Pérez Sánchez a Diego Polo y, en la actualidad reconocido como tal, fue en un principio asociado a la obra de Mateo Cerezo. Véase ANGULO IÑIGUEZ, D., PEREZ SANCHEZ, A.E.: La pintura madrileña del segundo..., op. cit., pp. 250-251. Otras referencias bibliográficas, también citadas por este autor, son: SOEHNER, H.: Spanische Maister. Alte Pinakotheke, Münich, 1962, pp. 40-63, lám. 94-95; PEREZ SANCHEZ, A.E.: «La obra de Diego Polo,...», op. cit., pp. 355, fig. 222; HOHENZOLLERN, J.G., Prinz von: Staatsgalerie Schleissheim. Verezeichnis der Gemälde. Münich, 1980, p. 80, núm. 959.

Se podría observar cierta relación con el cuadro dedicado a San Jerónimo existente en el monasterio de El Escorial, obra de Tiziano. Cfr. CAGLI, C., VALCANOVER, Fr.: La obra completa de Tiziano. Barcelona, 1974, lám. 423.
}

"CUADERNOS DE ESTUDIOS GALLEGOS", Tomo XLIII, Fascículo 108, Santiago 1996. 
cortante de las rocas -obsérvense las calidades silíceas de aquella sobre la que descansa su pie izquierdo- como por la hiedra que, por todas partes, trepa hasta los lugares más insospechados. En torno a San Jerónimo, colocado en una posición un tanto forzada a la que nos refiriremos más adelante, en una repetición fiel y minuciosa del contexto material que acompaña a su homónimo bávaro, se encuentra una cruz hecha a base de dos ramas entrelazadas, cuyo perfil nudoso y retorcido se repite en otras obras de Polo ${ }^{18}$, un reloj de arena, unos cuantos libros -uno de ellos tumbado-, un papel garabateado y una calavera, sobre la que apoya su mano izquierda; a su pies, aquí reside la diferencia con el cuadro de Münich, un león, mucho más fiero que el que el artista burgalés pintó en un segundo plano en el San Jerónimo flagelado del monasterio de El Escorial ${ }^{19}$, se revuelve violentamente, abriendo sus fauces y fijando su mirada fuera del ámbito espacial del lienzo, directamente sobre nosotros, lo que acentúa su intensidad dramática ${ }^{20}$.

No obstante, esta atribución no se asienta unicamente en la coincidencia del modelo. Si se analiza desde un punto de vista técnico, es posible comprobar como están presentes muchas de las características que individualizan a Diego Polo.

De este modo, la composición del tema, la marcada diagonal que describe el cuerpo del eremita, desde el ángulo inferior izquierdo al superior derecho, subrayado por otras líneas menores, se equilibra con la que

${ }^{18}$ Es el caso del San Jerónimo de El Museo del Prado. ANGULO IÑIGUEZ, D., PEREZ SANCHEZ, A.E.: La pintura madrileña del segundo..., op. cit., lám. 45, núm. 11.

${ }^{19}$ ANGULO IÑIGUEZ, D., PEREZ SANCHEZ, A.E.: La pintura madrileña del segundo..., op. cit., lám. 247, núm. 9.

${ }^{20}$ Desde un punto de vista iconográfico el valor simbólico de los objetos que rodean a un ermitaño y los modos de representación empleados véase MARTINEZ BURGOS GARCIA, P.: «Ut pictura natura: la imagen plástica del Santo Ermitaño en la literatura espiritual del siglo XVI», Norba-arte, IX, (1989), pp. 15-27. Este mismo autor profundiza en el tema de los «modus orandi» en el libro Idolos e imágenes. La Controversia del arte religioso en el siglo XVI español. Salamanca, 1990.

También es interesante recordar las palabras de Fr. Pacheco: «Pintese una calavera, Crucifixo o Cruz o Calvario y una trompeta al oído, por la continua memoria de la muerte y el juicio final, y muchos libros, porque en aquella soledad le ayudaban los estudios, junto con la mortificación de la carne... Píntese con venerable barba blanca, color tostado, de setenta y ocho años de edad...». PACHECO, Fr.: Arte de la pintura. Sevilla, 1649. (Ed. crítica de Bonaventura Bassegoda i Hugas. Madrid, 1990, pp. 641-644).

"CUADERNOS DE ESTUDIOS GALLEGOS", Tomo XLIII, Fascículo 108, Santiago 1996. 
-quizás más intuida que visible- se establece entre la luz que se derrama desde el vértice superior izquierdo y la mirada del santo, prolongándose en su brazo y en la calavera; esta estructura de líneas cruzadas en aspa crea un centro focal que viene a ser el rostro de San Jerónimo. Por otra parte, el esquema adoptado a la hora de componer la figura es el mismo, ligeramente modificado -la pierna derecha queda suspendida en el aire y la cabeza no se oculta tras el brazo alzado-, que se recoge en un dibujo procedente de una colección particular barcelonesa ${ }^{21}$.

Su filiación veneciana, que en muchas ocasiones ha conducido a atribuciones de tal índole ${ }^{22}$, queda patente tanto en el tratamiento lumínico de los fondos -éstos se disuelven entre vibrantes resplandores- como en su colorido, cálido e intenso, o en su pincelada ágil y ligera, cargada de destellos luminosos como se puede observar en la barba del Santo o en la melena del león. Igualmente, el modo de interpretar el desnudo lo delata como un perfecto conocedor de la técnica de Tiziano ${ }^{23}$ aunque su corporeidad, su volumen, la monumentalidad escultórica de la figura y, las calidades alcanzadas en sus carnaciones avanzan la influencia del mundo de Ribera ${ }^{24}$.

A ello habría que añadir aquellos datos que se pueden entender como parte del vocabulario formal del artista; nos referimos a la similitud entre los rostros del San Jerónimo de Ourense y el de El Escorial, a esa mirada extática, o a sus rasgos fisonómicos que repite en el cuadro que posee el Museo del Prado -en este último el arrobamiento de los anteriores es sustituido por una profunda melancolía-; a ciertos gestos como el dejar caer la cabeza sobre la mano derecha flexionando el brazo y haciendo que su bíceps se contraiga de un modo particular; o el excesivo alargamiento del derecho que, en los tres lienzos atribuidos a este maestro -el de El Esco-

\footnotetext{
${ }^{21}$ Dicho dibujo fue atribuido a Diego Polo por Pérez Sánchez en 1969. Véase PEREZ SANCHEZ, A.E.: «Diego Polo», op. cit., p. 52, lám. V; ANGULO IÑIGUEZ, D., PEREZ SANCHEZ, A.E.: A corpus of spanish drawnings. Volume two. Madrid school. 1600 to 1650. Londres, 1977, pp. 327-331.

${ }^{22}$ El San Jerónimo de la Alte Pinakothek de Münich en el inventario de la colección ducal de Manheim de 1780 fue relacionado con Bassano. ANGULO IÑIGUEZ, D., PEREZ SANCHEZ, A.E.: La pintura madrileña del segundo..., op. cit., p. 245.

${ }^{23}$ Cfr. PEREZ SANCHEZ, A.E.: «Diego Polo», op. cit., p. 47.

${ }^{24}$ Cfr. ANGULO IÑIGUEZ, D., PEREZ SANCHEZ, A.E.: La pintura madrileña del segundo..., op. cit., p. 244.
}

"CUADERNOS DE ESTUDIOS GALLEGOS", Tomo XLIII, Fascículo 108, Santiago 1996. 
rial, el del Prado (Lám. 4), y el de Münich- lo mismo que en el gallego, se cruza por delante del pecho del Santo ${ }^{25}$.

Este cuadro fue donado por el Deán don Antonio Francisco Salgado y Vergara en $1791^{26}$. Esto último reafirmaría la identificación de su autor con el menor de los Polo.

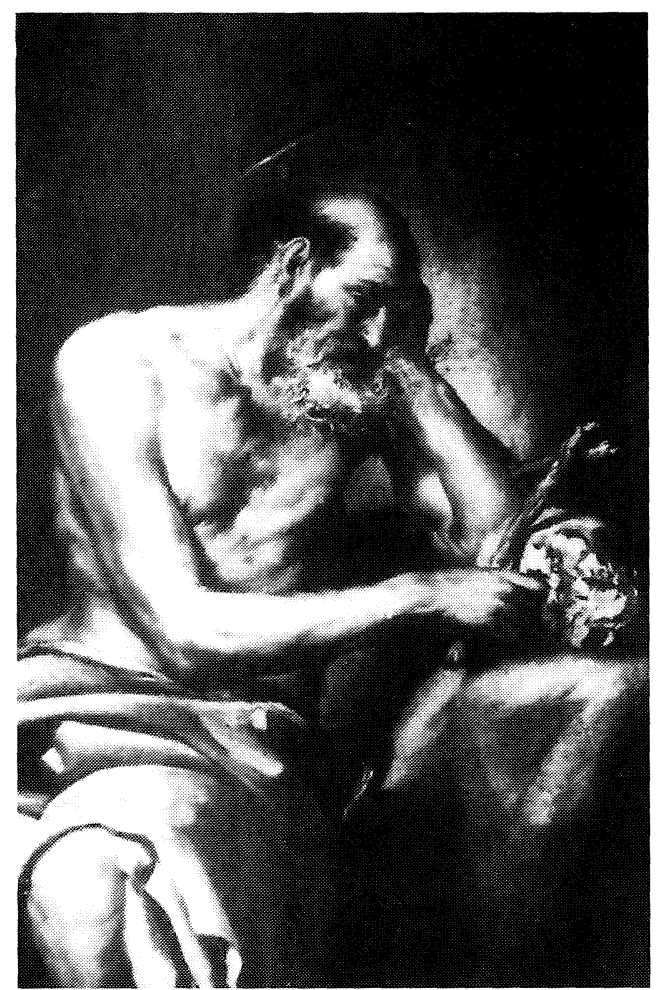

Lámina 4. San Jerónimo. Museo del Prado. Madrid.

${ }^{25}$ Quizás la mejor valoración que se puede hacer de esta tela son las palabras con que Angulo Iñiguez y Pérez Sánchez describen la obra de Münich: «...destaca la factura de las carnes, los paños resueltos en grandes planos sintéticos de una cierta dureza, que contrastan con el fondo del paisaje, de concepción y técnica enteramente venecianas, y aun evocando los fondos umbríos con hojas y ramas suspendidas del San Jerónimo de El Escorial, cuya oquedad luminosa envolviendo la cabeza del santo se repite aquí, aunque de modo evidentemente diverso.» ANGULO IÑIGUEZ, D., PEREZ SANCHEZ, A.E.: La pintura madrileña del segundo..., op. cit., p. 245.

${ }^{26}$ Cfr. YZQUIERDO PERRIN, R., GONZALEZ GARCIA, M.A., HERVELLA VAZQUEZ, J.: La Catedral de Orense. Orense, 1993, p. 141.

"CUADERNOS DE ESTUDIOS GALLEGOS", Tomo XLIII, Fascículo 108, Santiago 1996. 
Martirio de San Vicente. Iglesia parroquial de San Vicente do Pino de Monforte de Lemos ${ }^{27}$. (Láms. 5,6,7). El retablo mayor de San Vicente del Pino, una espléndida máquina levantada, al menos en su primer cuerpo, durante el cuatrienio de $1769-1773^{28}$, coincidiendo con el mandato de fray Benito Pérez ${ }^{29}$, fue realizado por un artista anónimo conocido con el apodo de «Mil Bienes $»^{30}$. Este, habiendo desplegado en su obra todo el esplendor del vocabulario rococó propio de mediados del siglo XVIII, supo, sin embargo, adaptar el espacio principal del mismo para un lienzo previo en el que se describe el martirio del Santo titular del templo.

Esta tela, fechada en su ángulo inferior izquierdo como de 1671, nos presenta uno de los martirios que sufrió San Vicente antes de su muerte, concretamente el del fuego, motivo por el cual fue asociado con San Lorenzo, siendo la única diferencia entre ellos la parrilla en la que cada uno de los Santos Diáconos es obligado a yacer ya que la del primero suele ir repleta de garfios de hierro que muerden sus carnes ${ }^{31}$.

${ }^{27}$ Autor: Taller de Bernardo de la Peña?. Cronología: 1671. Soporte: Lienzo. Técnica: Oleo. Estado: Bueno. Medidas: $300 \mathrm{cms}$. aprox. Localización: MONFORTE DE LEMOS. Monforte de Lemos. Iglesia parroquial de San Vicente do Pino. Retablo Mayor. (Monforte de Lemos).

${ }^{28}$ Archivo Histórico Nacional. Legajo 3556.

${ }^{29}$ VAZQUEZ, G.: Historia de Monforte y su tierra de Lemos. III. Pontevedra. 1971, p. 118; ARIAS, Pl.: «Monasterio de San Vicente de Monforte», Boletín de la Comisión de Monumentos de Lugo, 35, (1951), pp. 192-204.

${ }^{30}$ «Por su parte, el gran retablo del altar mayor, así como el sagrario, cuya traza, según se dice por tradición, fue debida a un monje de la casa, siendo desempeñado en su totalidad por un hijo de Monforte apodado Mil Bienes, no importa menos para el caso, porque recuerda en toda su extensión las construcciones de la época de Luís XV, como en las iglesias lusitanas. Este del que hablamos parece haber venido directamente del vecino reino: guarda de los de su clase todos los defectos, y es de los muy escasos de este estilo que cuenta Galicia, é inferior al altar mayor de la catedral de Lugo, que, debiéndose á arquitecto francés es ya más puro, si es que esto puede decirse de semejantes obras. El inmenso cuadro que llena su vano y representa el martirio de San Lorenzo, no se goza bien; pero a simple vista no parece tan malo que sea indigno de este recuerdo...». MURGUIA, M.: Galicia. Madrid. 1888. (Ed. facsímil de Justo G. Beramendi. Vigo. 1982, p. 1041-1042); AMOR MEILAN, M.: Lugo en Geografía General del Reino de Galicia. Barcelona, 1936, pp. 588, 591; PITA ANDRADE, J.M.: Monforte de Lemos. V. Santiago de Compostela, 1952, p. 34.

${ }^{31}$ FERGUSON, G.: Signos y símbolos en el Arte Cristiano. Buenos Aires, 1956, p. 213-214.

"CUADERNOS DE ESTUdIOS GALLEGOS", Tomo XLIII, Fascículo 108, Santiago 1996. 


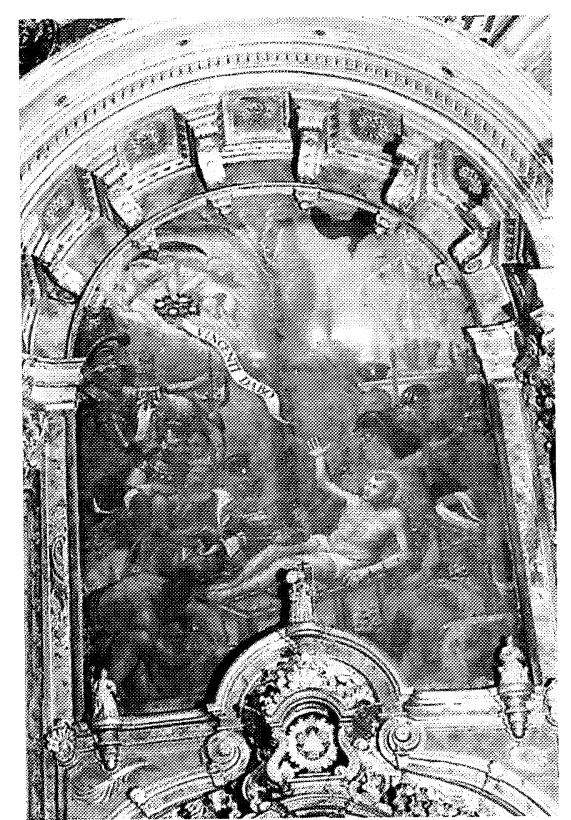

Lámina 5. Martirio de San Vicente.

Iglesia Parroquial de San Vicente del Pino. Monforte de Lemos.

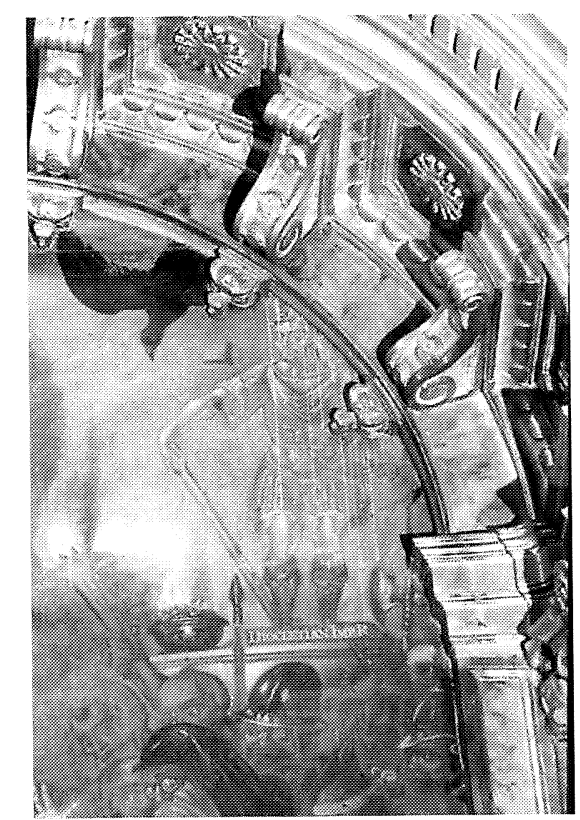

Lámina 7. Martirio de San Vicente. Detalle.

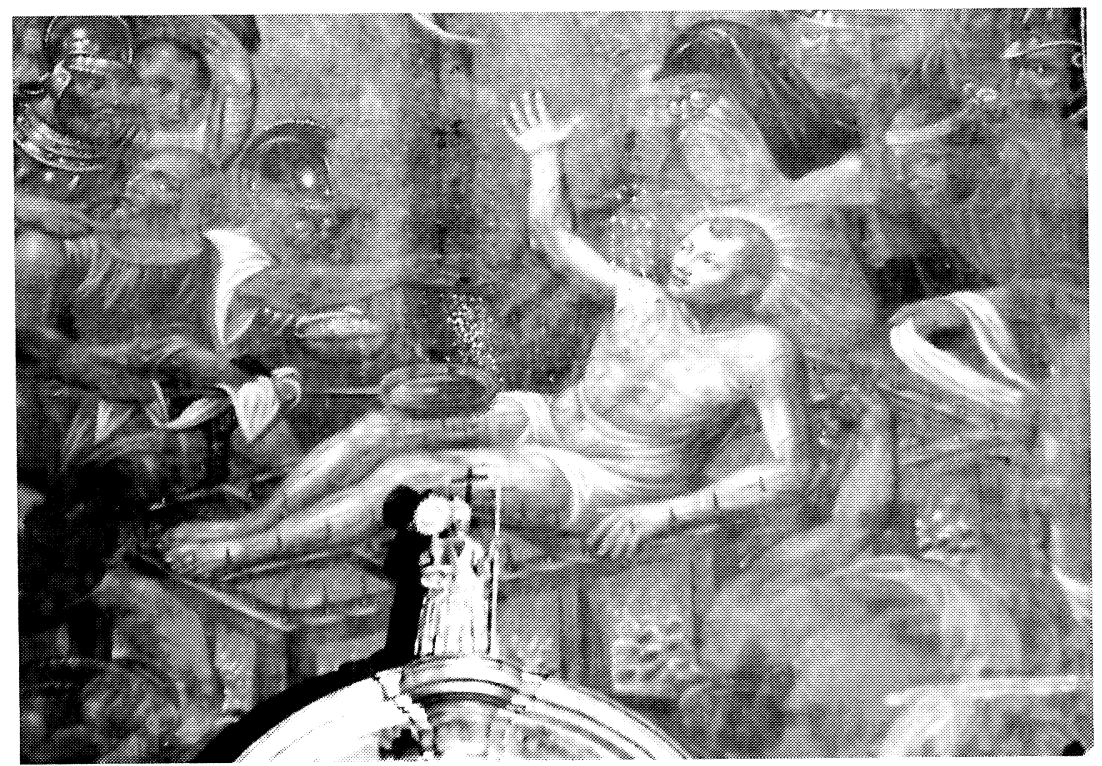

Lámina 6. Martirio de San Vicente. Detalle. 
La obra se mueve dentro de un lenguaje expresionista al que se adapta su iluminación de carácter tenebrista. Destacan, por ello, los rostros deformados -de tez oscura, ojos saltones y rasgos bestiales- de los verdugos del santo que contrastan tanto con la figura de éste como con los dos ángeles que descienden desde el ángulo superior izquierdo portando una corona de flores y la palma del martirio, ésta medio escondida ${ }^{32}$.

La composición de la escena es lo más sobresaliente de un lienzo cuyo dibujo -siendo aceptable- presenta multitud de incorrecciones. En ella se establece un eje principal marcado por la parrilla sobre la que se tiende San Vicente; sin embargo, uno de los espacios consiguientes a esta disposición desaparece ante la multitud de soldados y sayones que se abalanzan sobre el Mártir; únicamente en el ángulo superior derecho parece existir un espacio abierto en el cual podemos contemplar una estatua de Diocleciano -DIOCLETIAN IMP. R. -, que nos sorprende por cierto espíritu arqueológico que se intuye en ella, y un cuervo que desciende hacia San Vicente ${ }^{33}$.

Si observamos detenidamente esta obra, podemos comprobar como su relación con un posible taller dirigido por Bernardo de la Peña es probable. Al margen de su fecha, esta obra habría sido pintada un año después de la Oración en el Huerto y el Descendimiento situados en la tribuna -todavía durante el mandato de fray Marcos Morales-, se puede apreciar como los personajes poseen el mismo tipo de rostro deformado y caricaturesco y, tal vez, lo que es más importante, la escena del martirio está directamente inspirada en el Martirio de San Lorenzo de El Escorial

${ }^{32}$ Desde la corona floral desciende hacia el Santo una filacteria en la que se puede leer VICENTI DABO.

${ }^{33}$ Este hace referencia al episodio en que tras haber sido arrojado el cuerpo del Santo a las fieras, fue protegido de los ataques de aquellas por un cuervo.

«En Valencia, en la corona de Aragón, San Vicente levita y mártir, ... por sentencia del imperio ... sufrió por la gloria de Christo estrechas cárceles, hambre, tormento del éculo, parrillas de hierro encendido y otras máchinas de tormento... Como un cuervo, ave perezosa, y muy pausada, que no estaba muy distante, demostrando en cierto modo con su tétrica figura, que estaba llorando, ahuyentó lexos del cuerpo con cierto ímpetu las demás aves, que se iban acercando, aún a aquellas que eran más de temer por su mayor ligereza de vuelo...». INTERIAN DE AYALA, J.: Pictor Christianus... op. cit., II, p. 79).

"CUADERNOS DE ESTUDIOS GALLEGOS", Tomo XLIII, Fascículo 108, Santiago 1996. 
que Tiziano pintó en $1567^{34}$.

En efecto, como en aquella, San Vicente se incorpora de su ardiende lecho alzando su mano hacia dos ángeles que descienden con la finalidad de coronarlo; varios soldados a caballo ordenan al resto de los verdugos que inicien sus torturas y uno de ellos se encorva para avivar el fuego ${ }^{35}$.

${ }^{34}$ «Las pinturas religiosas fueron, sin duda alguna, lo más conocido y las que de un modo más directo y temprano pudieron ejercer su influencia sobre nuestros artistas. Buena parte de ellas eran visibles en El Escorial, lugar frecuentado por pintores y meta obligada de cuantos viajeros y estudiosos llegaban a la Corte. Repeticiones de taller y copias más o menos directas, poseyeron casi todos los grandes de la nobleza y podían ser también conocidos con facilidad, especialmente en el medio madrileño. Pero además la estampa se encargó muy pronto de hacer llegar las composiciones tizianescas a lugares más distantes. Allí donde no puede señalarse la huella técnica personalísima del maestro, podemos recoger la impronta de la peculiar iconografía de sus composiciones más difundidas a través del grabado». PEREZ SANCHEZ, A.E.: «Presencia de Tiziano en la España del siglo de Oro», Goya, 135, (1976), p. 140; CAGLI, C., VALCANOVER, Fr.: La obra completa de Tiziano..., op. cit., cat. 399, 474.

Por su parte Interian de Ayala comenta que «hay,..., en Salamanca una insigne Pintura, y muy grande, que dicen ser de Vicente Carducho, en que representa echado a San Vicente sobre las parrillas encendidas, con tal propiedad, y elegancia, que no cabe más, y que pediría mucho tiempo describirla y elogiarla». INTERIAN DE AYALA, J.: Pictor Christianus Eruditus..., op. cit., II, p. 79.

García Gainza ha dado a conocer recientemente una obra inédita de Pedro Orrente que repite este tema de manera muy similar. GARCIA GAINZA, C.: «El Martirio de San Lorenzo. Una obra inédita de Pedro Orrente», Archivo Español de Arte, LXII, 252, (1990), pp. 658-660, fig. 19.

${ }^{35}$ Algunos de los rasgos descritos aparecen recogidos en uno de los grabados que ilustran la obra de Gallonio. GALLONIO, A.: Trattato de Gli Instrumenti di Martirio e dell varie manieri di Martoriare usate de Gentili contro christiani. Roma, Ascanio Girolamo Donangeli, 1591, p. 87.

También existe gran semejanza con lo narrado en las Actas de los Mártires: «Bajado entonces Vicente del caballete, fué llevado por sus verdugos al suplicio del fuego, y adelantándose casi a sus atormentadores, cuya lentitud reprendía, caminaba presuroso al sufrimiento. En efecto, mandó el feroz esbirro traer el lecho con sus barras de hierro, y que, amontonando debajo carbón, pusieran en él al mártir de Dios para abrasarle las carnes. Así, pues, el intrépido atleta de Dios sube por sí mismo a la máquina de hierro candente. Es atormentado, flagelado, abrasado y, con sus miembros descoyuntados, se crece para el dolor. Le aplican también al pecho y miembros la apretada aspereza de las láminas rugientes $\mathrm{y}$, al correr por las puntas del hierro candente el licor, la estridente llama se rocía de grasa. Las llagas hieren otras llagas; los tormentos se ensañan sobre tormentos. Granos de sal, que crepitan esparcidos en el fuego, salpican los miembros del mártir y son como saetas que se disparan, no ya sólo sobre su piel lacerada, sino sobre

"CUADERNOS DE ESTUDIOS GALLEGOS", Tomo XLIII, Fascículo 108, Santiago 1996. 
El pintor de Monforte, seguramente sirviéndose de una estampa, sólo ha invertido la posición de los personajes y, si acaso, ha sustituido las horquillas por recipientes con aceite y la imagen de un dios pagano por la del emperador Diocleciano. Este ha recreado la composición del maestro veneciano pero ha sido incapaz de repetir la sensualidad de su toque, la riqueza de su paleta o el sentido vibrante y dramático de la iluminación nocturna a base de antorchas ${ }^{36}$.

San Simón y San Bartolomé. Iglesia parroquial de San Salvador de Vilanova de Lourenzá ${ }^{37}$. Estos dos lienzos debieron estar, en su momento, incluidos dentro de una serie más amplia dedicada a los apóstoles. Sus dimensiones y las características formales de ambos parecen justificar esta afirmación.

Se nos presentan como figuras de busto entero, ligeramente terciadas, situadas sobre un paisaje umbrío escasamente iluminado, sólo en el fondo se llega a distinguir el destello de una luz de atardecer, un resplandor en el horizonte de clara tradición veneciana. Sus gestos, medidos y equilibrados, se caracterizan por su solemnidad, mucho más acusada en la figura de San Simón que en la de San Bartolomé ${ }^{38}$. Sus colores, oscuros y opacos, predominando los carmines y azules ${ }^{39}$, revelan -dentro de su sobriedad- cierta facilidad y gusto para su aplicación. La iluminación conserva un claro sentido tenebrista que le permite subrayar ciertas partes del personaje representado, sobre todo el rostro y las manos.

sus mismas recónditas entrañas. Y como ya no quedaba parte alguna entera del cuerpo, una llaga renueva otra llaga. Sin embargo, el siervo de Dios permanece inconmovible, y levantados al cielo los ojos, oraba al Señor». RUIZ BUENO, D.: Actas de los Mártires. Madrid, 1987, pp. 1008-1009.

${ }^{36}$ Es interesante señalar como el artista interpreta incorrectamente ciertos datos de la obra ya por incapacidad -transforma el rompimiento de gloria en una densa humareda a través de la que los ángeles deben abrirse paso- ya por una deficiente lectura de la misma -a los pies de la estatua de Diocleciano se puede ver una especie de brasero que en el original es, en realidad, el pebetero de una antorcha-.

${ }^{37}$ Autor: Círculo de Alonso del Arco. Cronología: Ultimo tercio del siglo XVII. Soporte: Lienzo. Técnica: Oleo. Estado: Muy sucios; con numerosos repintes y barnices oxidados que afean el efecto de conjunto.Medidas: 115 x $84 \mathrm{cms}$. Localización: VILANOVA DE LOURENZA. Vilanova de Lourenza. Iglesia parroquial de San Salvador. Museo. (Mondoñedo).

${ }^{38}$ Quizás el grado de deterioro y suciedad presentes en este último lienzo le resten calidad, pareciéndonos muy superior el dedicado a Simón.

${ }^{39}$ Seguramente ese sea el color original de la túnica de San Simón, hoy negra.

"CUADERNOS DE ESTUDIOS GALLEGOS", Tomo XLIII, Fascículo 108, Santiago 1996. 
Uno de los rasgos más destacables de estos lienzos es la diferencia que se observa en la ejecución del dibujo entre uno y otro; mientras que en el de San Simón la figura adquiere concreción y peso a través del plegado de su manto, en el de San Bartolomé se aprecia cierta planitud que va acompañada de un dibujo un tanto descuidado y flojo e incorrecciones en las proporciones de su cuerpo. Excelente debió ser, sin embargo, la configuración de sus rostros en los que se observa un gran apego a la realidad, sin idealizar sus facciones, que ha llevado en más de una ocasión a compararlos con los apostolados de Ribera ${ }^{40}$.

San Simón. (Láms. 8,9) Este, identificado por su nombre que está escrito en la parte inferior de la tela sobre un fondo blanco, aparece sosteniendo con su mano derecha la sierra con que fue martirizado -ésta por efecto de la luz parece una gran espada- mientras que en la izquierda muestra un libro abierto.

Su interés se cifra en que a través de él, concretamente del modelo empleado para su realización, se puede localizar su origen. Efectivamente, se trata de la repetición fiel del modelo utilizado para pintar un apóstol San Pablo que se guardó en la catedral de Oviedo y que, en la actualidad, se encuentra incluido dentro de una colección particular de la capital asturiana $^{41}$.

Como en aquél existen ciertos rasgos estilísticos -al margen de los ya comentados- que nos permiten establecer una filiación próxima a Alonso del Arco (1635-1704) ${ }^{42}$. Así, es muy sorprendente la diferencia de cali-

\footnotetext{
${ }^{40}$ Sobre estos apostolados puede verse: PEREZ SANCHEZ, A.E., SPINOSA, N.: Ribera (1591-1652). Madrid, 1992, pp. 248-261.

Su relación con Ribera ha sido indicada por Chavarría Pacios que comenta lo siguiente: «Al pasar de la sala segunda a la tercera, siguiendo por el lado izquierdo, nos encontramos con dos lienzos similares: San Simón y San Bartolomé. Por su tenebrismo y pureza de sus líneas un pintor notable opinaba que eran de Ribera o de su Escuela». CHAVARRIA PACIO, C.: El Monasterio de San Salvador de Lorenzana y su Museo de Arte Sacro. Lugo, 1991, p. 61.

${ }^{41}$ Sobre el cuadro ovetense, firmado por Alonso del Arco, véase: GONZALEZ SANTOS, J.: «Obras de Alonso del Arco en Asturias», Liño, 5, (1985), pp. 227-232, láms. 4, 5.

${ }^{42}$ Sobre este pintor madrileño, discípulo de Pereda, siguen siendo de consulta obligada los estudios realizados por GALINDO SAN MIGUEL, N.: «Alonso del Arco», Archivo Español del Arte, XLV, (1972), pp. 347-385; GALINDO SAN MIGUEL, N.: «Alonso del Arco, un fresquista inédito», Boletín del Seminario de Arte y Arqueología, XLVI, (1980), pp. 451-460; VALDIVIESO, E.: "Tres pinturas de Alonso del Arco», Boletín del Seminario de Arte y Arqueología, XXXVI, (1970), pp. 521-526.
}

"CUADERNOS DE ESTUDIOS GALLEGOS", Tomo XLIII, Fascículo 108, Santiago 1996. 


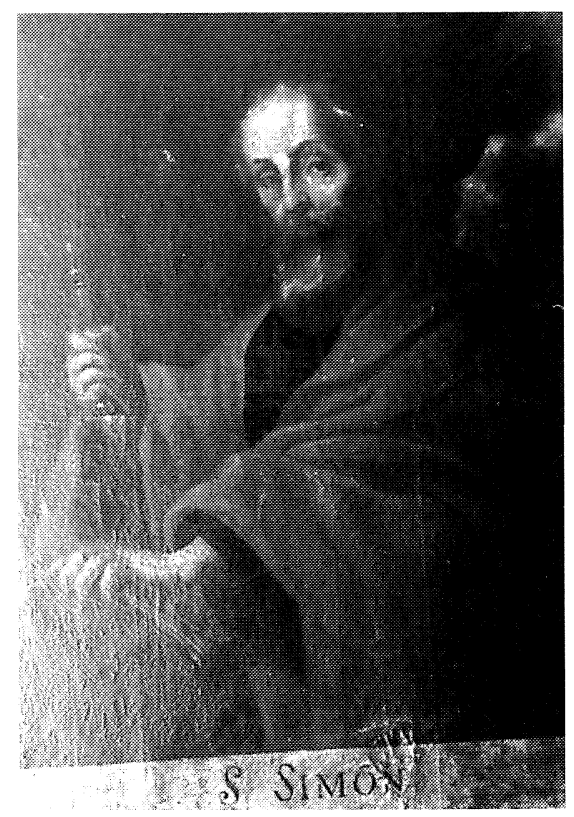

Lámina 8. San Simón. Iglesia Parroquial de San Salvador de Vilanova de Lourenzá. Museo.

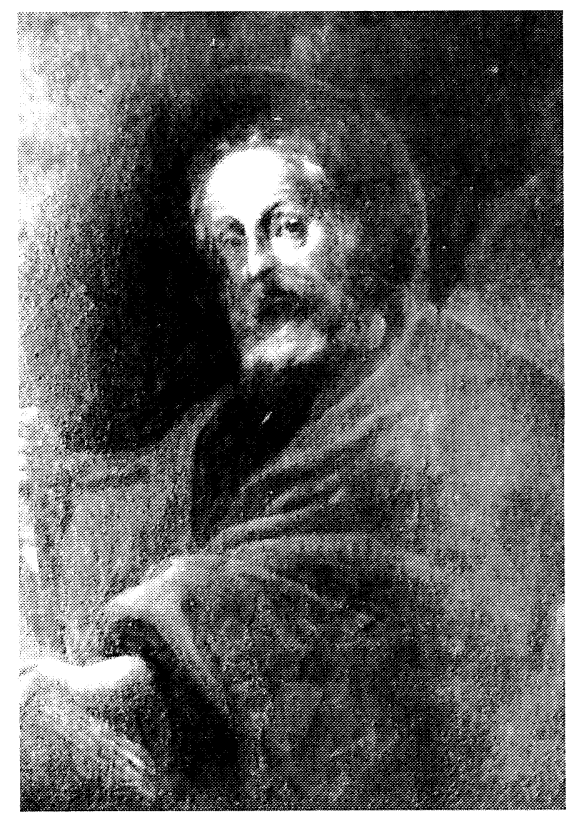

Lámina 9. San Pablo. Colección Particular. Oviedo.

dad entre los dos lienzos de Lourenzá, vinculable a la premura de los encargos contratados por la esposa del pintor y a la presencia de un nutrido taller «que bosquejaba el cuadro tomando la composición de una estampa» para que, más tarde, Alonso lo retocase ${ }^{43}$.

Más significativa es la coincidencia en detalles tan minúsculos como la artrosis que se aprecia en los dedos de ambos apóstoles -nos referimos a San Simón y San Pablo- sobre la cual no podemos afirmar sí es producto de una mayor fidelidad al modelo o de la rudeza del dibujo del pintor ${ }^{44}$.

San Bartolomé. (Lám. 10) Responde a los mismos rasgos citados con anterioridad. Ahora el Santo sostiene el cuchillo con que fue desollado.

Su posición, con la cabeza elevada hacia el cielo y la mano derecha vuelta hacia el pecho, nos recuerda una composición muy similar utiliza-

\footnotetext{
${ }^{43}$ GALINDO SAN MIGUEL, N.: «Alonso del Arco»..., op. cit., p. 351.

${ }^{44}$ GONZALEZ SANTOS, J.: «Obras de Alonso del Arco en...», op. cit., p. 228.
}

"CUADERNOS DE ESTUDIOS GALLEGOS", Tomo XLIII, Fascículo 108, Santiago 1996. 


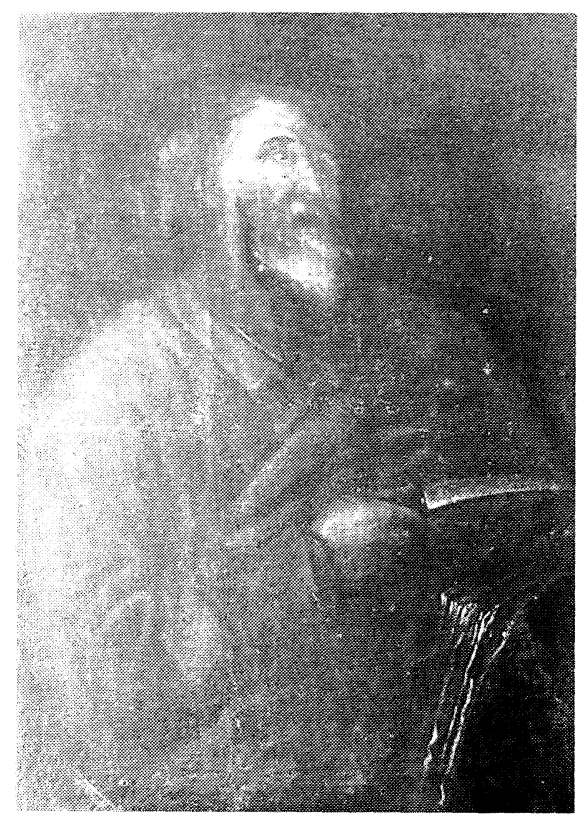

Lámina 10. San Bartolomé. Iglesia Parroquial de San Salvador de Vilanova de Lourenzá. Museo.

da por Antonio Pereda en el San Pedro de las Carmelitas de Toledo ${ }^{45}$; este hecho confirma lo señalado por Galindo San Miguel al decir que «su principal fuente de inspiración son las obras de su maestro, que a veces copia casi al pie de la letra, y los grabados» ${ }^{46}$.

Asimismo es característico de este pintor el empleo de pinceladas de color blanco para conseguir efectos lumínicos más acusados que nos lo ponen en relación con los bodegones y vanitas realizadas por su maestro.

${ }^{45}$ ANGULO IÑIGUEZ, D., PEREZ SANCHEZ, A.E.: Pintura madrileña del segundo tercio del siglo XVII. Madrid, 1983, lám. 166.

Este mismo modelo fue el que utilizó en el San Pedro y San Pablo del banco del retablo del Bautismo de Cristo de 1702 de la iglesia toledana de San Ildefonso.

El tema del apostolado lo volvemos a encontrar dentro del catálogo de la obra de Alonso del Arco en el atico del retablo de San Lope, en la iglesia parroquial de Cubillos del Sil, León. GALINDO SAN MIGUEL, N.: «Alonso del Arco»..., op. cit., p. 358, 380; URREA, J.: «Notas para el estudio del arte de León V. La pintura del siglo XVII en León», Tierras de León, XVII, 29, (1977), pp. 31-33.

${ }^{46}$ GALINDO SAN MIGUEL, N.: «Alonso del Arco»..., op. cit., p. 355.

"CUADERNOS DE ESTUdIOS GALLEGOS", Tomo XLIII, Fascículo 108, Santiago 1996. 
Parece obvio, por lo tanto, que estamos, en el peor de los casos, ante dos obras cercanas al círculo de Alonso del Arco cuya identidad real seguramente podrá ser descubierta si en algún momento se retiran esas bandas en las que figuran los nombres de los Santos.

Su presencia en Lourenzá, al márgen de la estrecha relación que unió, desde siempre, la diócesis mindoniense con la de Oviedo, se debe poner en relación con alguno de los abades que gobernó el monasterio en el último tercio del siglo XVII. Sólo como hipótesis aventuramos el nombre de fray Francisco Alvarez quien, además de ser abad de Vilanova, fue vicario de las monjas de San Plácido de Madrid y procurador general de la Cancillería de Valladolid ${ }^{47}$.

La datación precisa es prácticamente imposible de dar ya que, si bien, su obra está firmada y fechada en multitud de ocasiones, las diferencias estilísticas entre las primeras y las últimas son mínimas.

Martirio de Santa Mariña de Aguasantas. Iglesia parroquial de Santa Mariña de Aguasantas ${ }^{48}$. (Lám. 11) La iglesia de Santa Mariña de Aguasantas ha estado ligada a dos hechos fundamentales, a lo largo de toda su existencia; por una parte, aquel legendario que asocia este lugar con la vida, la muerte y los milagros de Santa Mariña ${ }^{49}$; y por otra, desde un punto de vista histórico, Aguasantas fue cedida por el real patronato en 1627 al obispado de Ourense, en una permuta con el señorío de la $\operatorname{ciudad}^{50}$. Este último hecho terminó por transformar a esta localidad, situada en el valle de Rábade, en residencia episcopal veraniega, dadas las condiciones climáticas que poseía -«El día tres de Julio de este presente

${ }^{47}$ PEREIRA, M.: «Monasterio de San Salvador de Lorenzana. Apuntes para su Historia», Boletín de la Comisión de Monumentos de Lugo, I, 5, (1945), p. 110.

${ }^{48}$ Autor: Círculo de los Peti. Cronología: 1719-1726. Soporte: Lienzo. Técnica: Oleo. Estado: Los abundantes repintes que ha sufrido este lienzo han desvirtuado tanto su ejecución como su composición. Fuertemente craquelado muestra faltas de pigmento en toda su superficie. Medidas: $168 \mathrm{cms}$. de ancho. Localización: ALLARIZ. Aguasantas. Iglesia parroquial de Santa Mariña. Capilla de Santo Tomé. (Allariz).

${ }^{49}$ Véase CALVO, F.: «Recuerdos de Aguas Santas», Boletín de la Comisión Provincial de Monuméntos de Ourense, IV, 91, (1913), pp. 321-330; 92, pp. 345-352; 93, pp. 883-389; V, 94, pp. 15-22.

${ }^{50}$ RISCO, V.: Provincia de Orense, en Geografía General de Galicia, (Ed. facsímil, A Coruña, 1980, X, p. 358).

"CUADERNOS DE ESTUDIOS GALLEGOS", Tomo XLIII, Fascículo 108, Santiago 1996. 


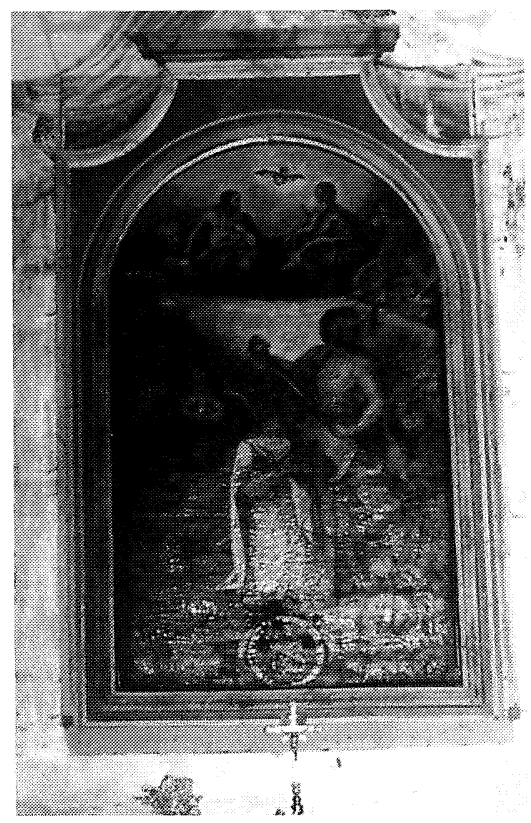

Lámina 11. Martirio de Santa Mariña de Aguasantas. Iglesia Parroquial de Santa Mariña de Aguasantas.

año, me retiré a este lugar de Aguas Santas, suelo para el estío de Benignísimo clima.... ${ }^{51}-$.

El culto a esta Santa, ya como hermana de Santa Liberata o Santa Librada, ya como mártir singular de las tierras orensanas o, incluso, como una confusión con Santa Margarita de Antioquía ${ }^{52}$, tuvo una gran popula-

\footnotetext{
${ }^{51}$ Unas páginas antes describe el lugar con los siguientes términos: «Las vozes repetidas de la bondad, y conveniencia del sitio de Aguas Santas donde padeció, y descansa el Cuerpo de Santa Marina; à cuya vista, y con el mayor retiro, se tranquiliza el ánimo, y con sus ayres puros, y aguas milagrosas, y frescas, se hazen mas tolerables los calores del Estío, me movieron à elegir esta estancia para los meses de Julio, Agosto y Septiembre, en los dos años de mil setecientos y diez y ocho, y el de mil setecientos y diez y nueve...». MUÑOZ DE LA CUEVA, J.: Noticias históricas de la Santa Iglesia Cathedral de Orense. Madrid, Imp. Real Joseph Rodríguez de Escobar, 1727, p. 26, 90.

${ }^{52}$ Sobre este aspecto, evidentemente de marcado carácter hagiográfico, se han centrado entre otros autores: HENRIQUEZ DE ABREU, P.: Vida et martirio da gloriosa Sta. Quiteria et de sues oyto irmaâs con un discurso sobre a ciudade Cinaniao Cinimia de Valerio Maximo. S.1., 1651; GANDARA, F. de la: El Cisne Oriental canta palmas y
}

"CUADERNOS DE ESTUDIOS GALLEGOS", Tomo XLIII, Fascículo 108, Santiago 1996. 
ridad y difusión desde un primer momento ${ }^{53}$, no obstante, su gran impulsor fue, en el primer cuarto de siglo XVIII, fray Juan Muñoz de la Cueva, cabeza de la diócesis auriense. Cuando él llega, al describir la parroquia, aparte de referirse a su templo -magnífico edificio de los siglos XII-XIII-, menciona dentro de su atrio una pequeña capilla dedicada a Santo Tomé ${ }^{54}$ aneja a la casa-palacio de los obispos y hoy rectoral. En su interior, presidiendo el altar mayor, se encuentra un gran lienzo en el que se representa el Martirio de Santa Mariña.

Desgraciadamente, este cuadro que Chamoso Lamas define, de forma muy acertada, como muy mediano, ha sufrido una gran cantidad de repintes que han ido desluciendo su escasa calidad. Sin embargo, todavía es posible atisbar algunas de sus características. De este modo, la escena se divi-

triunfos eclesiásticos de Galicia. Madrid, 1678; MUÑOZ DE LA CUEVA, J.: Noticias históricas de..., op. cit.; HUERTA Y VEGA, X. M. de la, Fr.: Anales del reino de Galicia. Santiago, 1733; FLOREZ, E.: España Sagrada. Teatro Geographico-histórico de la Iglesia de España. Orense. XVII, Madrid, oficina de Antonio Marín, 1763.

${ }^{53}$ «Entre Orense y Celanova, à un lado esta á el lugarito pequeño con este nombre y con la memoria de la iglesia del Martirio de S. Marina, mostrándose allí un horno donde la metieron, y llamado de Aguas Santas á la Fuente que allí hay, porque dicen tiene de la Santa Martir el ser saludable... También afirman está allí en la iglesia su Cuerpo Santo. De todo esto no hay más testimonio ni memoria auténtica que la tradición que ha venido de unos a otros y que puede creerse que ésta es antiquísima...» MORALES, A. de: Viaje a los reinos de León, y Galicia, y principado de Asturias. Madrid, Antonio Marín, 1765. (Ed. facsímil de J. Ma. Ortiz Juárez, Oviedo, 1977, p. 157).

${ }^{54}$ «A treinta passos de la principal Iglesia, está la capilla dedicada en lo antiguo à Santo Thomàs; y arruinada esta con ayuda de quien no debiera, se ha reedificado con más decencia después por otro, que según su puesto debió. Dentro de esta Capilla está la primera fuente, que brotó al contacto de la cabeza cortada de la Santa: fuente milagrosa entre todas, y adonde no solo de todo el Obispado, sino de todo el reyno, y fuera de él, acuden todo el año muchas gentes a buscar la salud de sus enfermedades y males...».

La advocación a este santo que aparece en el lienzo que nos disponemos a analizar, debe justificarse a través de los datos que aporta el citado obispo: «... y aviendo fundado en esta Gonçalo, y su muger Ilduara, un Convento de Canónigos Reglares en el año de novecientos y setenta y siete, aunque no es cierto si su Templo magnifico se edificó algunos años después, por su fábrica se colige que el Templo de Santa Marina le compite en antigédad...». MUÑ̃Z DE LA CUEVA, J.: Noticias históricas de..., op. cit., p. 67, 75. No es extraño que esta comunidad tenga como patrono a Santo Tomé ya que, tanto a éste como al fundador de la Orden, San Agustín, los une un mismo milagro, el cíngulo que la Virgen les había entregado a ambos. Cfr. FERGUSON, G.: Signos y símbolos en el Arte Cristiano. Buenos Aires, 1956, p. 211; MALE, E.: El Barroco..., op. cit., p. 374.

"CUADERNOS DE ESTUDIOS GALLEGOS", Tomo XLIII, Fascículo 108, Santiago 1996. 
de en dos partes, una celestial y otra terrena; en medio de ambas, Santo Tomé hace de supremo mediador. En la parte inferior, se nos narra la decapitación de Santa Mariña; su cabeza, ya lívida, ha rodado por el suelo, su cuerpo, todavía de rodillas, mantiene la actitud de oración con que fue martirizada; su verdugo, desplegando un poderoso gesto teatral, se dispone a envainar su espada mientras que, tras él, otro personaje observa, desde las sombras, los acontecimientos ${ }^{55}$. En un plano intermedio, Santo Tomé desciende portando la corona de flores que simboliza el triunfo de la mártir y la alabarda, instrumento de su martirio -a sus pies figura el nombre STO TOME ${ }^{56}$. Por último, la parte superior está ocupada por un rompimiento de Gloria en el cual, en medio de querubines y angelotes -envueltos en una luz dorada- aparece la Santísima Trinidad.

Si bien, como se ha dicho, los retoques que esta tela ha padecido han transformado la aparición celestial en un modelo clasicista, quedando tan sólo unos ángeles que, con forzados escorzos, descienden desde el ángulo derecho; han mudado el rostro del verdugo, Malco, hasta convertirlo en una cara regordeta, sonrojada, y casi nos atreveríamos a decir que de borrachín; y han anulado toda la fuerza expresiva y emocional que traduce su gesto, todavía se puede comprobar su calidad en los rostros de Santo Tomé o en el esbirro que se oculta tras Malco.

Es inútil pretender analizar la paleta o la iluminación que su autor quiso utilizar; a pesar de ello, su concepción general -el optar por el dramatismo del martirio ya consumado, sin concesiones a la piedad o a un cierto idealismo, en vez de preferir el momento previo a la ejecución-

${ }^{55}$ Estas dos figuras son la mejor prueba de la relación que une este lienzo con la obra de los Peti. Cfr. MONTERROSO MONTERO, J.M.: «As pinturas da capela do Santo Cristo da Catedral de Ourense», A Capela do Santo Cristo de Ourense. Catedral de Ourense. Cuadernos do Restauro. A Coruña. 1996. pp. 66-85.

${ }^{56}$ Que sea Santo Tomás el que corone a Santa Mariña no deja de ser «una feliz coincidencia» si, tal como dice La Leyenda Dorada, éste sufrió entre otros martirios previos a su muerte aquellos que padeció ésta -»Irritado el rey, mandó que extendieran por el suelo varias láminas de hierro incandescente y que colocaran sobre ellas al apóstol con los pies desnudos; pero Dios dispuso que en el momento en que Tomás posó sus plantas sobre las dichas láminas, de entre ellas surgieran en forma de surtidores varios chorros de agua que inmeditamente extinguieron su incandescencia. Por consejo de Casisio ordenó el rey que encerraran al siervo de Cristo en un horno encendido, cuyo fuego se apagó en cuanto el apóstol penetró en él; y de él salió sano y salvo al día siguiente...»VORAGINE, S. de: La leyenda dorada. I. Madrid, 1992, p. 51.

"CUADERNOS DE ESTUDIOS GALLEGOS", Tomo XLIII, Fascículo 108, Santiago 1996. 
demuestra esa ferocidad con que, desde el siglo XVII, se pretendió mover e impactar, en sus resortes más íntimos, la conciencia del fiel ${ }^{57}$.

Su datación debe ponerse en relación con la labor realizada por Muñoz de la Cueva, concretamente, en los años que van desde noviembre de 1719 -fecha en que se redacta su Tratado sobre la vida de Santa Marina de Agua Santas-, y julio de 1726, momento en el que predica en esta iglesia un sermón en el cual hace referencia al emblema que aparece en la parte baja de la obra ${ }^{58}$.

Nos resta, por lo tanto, explicar cual es el significado del mismo. Este consta de una parte gráfica, en la que podemos entrever un ciervo que se dispone a beber en una fuente y una leyenda -»AD FONTES AQVARUMSICUT CERVUS DESIDERAT-. Su explicación, el hecho de haber elegido este motivo, nos la da el propio prelado orensano al comentar un texto de Isaías referente a la salvación gratuita -»¡ $\mathrm{Oh}$, todos los que teneis sed,

\footnotetext{
${ }^{57}$ La mejor descripción que podemos dar de este cuadro es la misma narración que del martirio hace Muñoz de la Cueva: «Triunfando Marina de tantos, y tan atroces tormentos, desesperado, y despechado Olibrio, mandò à un verdugo, que se llamaba Malco, que desembaynasse el azero, y cortasse la cabeza à la que si antes idolatrò su amor, ya por la constancia de su Fè, y su pureza virginal, le avergonçaba, y confundia. Partió el verdugo à executar el golpe; y retira à pocos passos de Armea esta Santissima Virgen, pidió à Malco, que le diesse lugar de hazer una breve oración, antes de cortarle el cuello. Condescendio cortes, y compasivo el verdugo: y levantando Marina su espiritu, y su voz à Jesu Christo su Esposo, le dio humildisimas gracias por averla librado de las torpes inmundicias, y por averla assistido, y sacado vencedora de tantas, y tales penas. Pidiole, con la confiança de Esposa tan fina, y tan amante, que para bien de la Iglesia, y de los Fieles, hiziesse saludable su intercession para todos sus devotos; y que todos los que la invocassen con Fè, y corazones limpios, hallassen para sus males en esta vida remedio, y gracia para la penitencia... Haziendo esta oración, se le apareció, y mostró Nuestro Señor Jesu Christo, acompañado de los Angélicos Coros:... Executo Malco el golpe, aunque estaba atónito, y como fuera de sí con tantas maravillas y portentos celestiales... Cayendo en tierra la sagrada cabeza de Marina se multiplicaron las demostraciones del Divino Poder...». En ella podemos ver el mismo sentido trágico del lienzo, sin embargo, en aquella se le añade la ternura poética de los siguientes versos: «Ven, Marina de Galicia,/ Esposa del Rey Eterno,/A recibir la Corona,/Inmarcesible del Cielo./Ven, fina Esposa de Christo/Los Seraphines Supremos/Clamaban en tu martyrio,/Admirados y suspensos». MUÑOZ DE LA CUEVA, J.: Noticias históricas de..., op. cit., p. 54, 79.

${ }^{58}$ Bajo este emblema aparece el escudo de armas del obispo orensano: el capelo episcopal con la cruz de malta cuyos brazos van en gul y azur, como se puede observar en su retrato, localizado en la sacristía de la iglesia.
}

"CUADERNOS DE ESTUDIOS GALLEGOS", Tomo XLIII, Fascículo 108, Santiago 1996. 
venid a las aguas, -aún los que no teneis dinero-!» (Is. 55. 1) $)^{59}$. Aparte, es posible completar dicho discurso, ampliar su proyección, a través de dos emblemas en los que el ciervo, al menos en parte, recupera aquel valor significante por el cual, según San Ambrosio, este animal era el símbolo de las doncellas ya que, la primera de las mártires, Santa Tecla, aplastó con sus pies y abatió, como el ciervo, a la antigua serpiente, apresurándose a apagar su sed en las fuentes del Salvador ${ }^{60}$. Dichos emblemas son el número 24 -ENSE RECIDENDUM- de la obra de Jeremías Reusnervs, Dedicatio Nicolaus Reusner, Emblemata... partim ethica, et physica: partim... historia et hyeroglyphica... (Francfurt, 1581) ${ }^{61}$, y el número 90, de la centuria I -OCCIDO ET MANDUCO- de Sebastián de Covarrubias $^{62}$.

\footnotetext{
${ }^{59}$ «Venid, hijos carissimos; venid todos los que os hallareis sedientos; venid à estas Montañas de Aguas Santas; y advertid, que no es mío este dicho, sino del mismo Dios, que os combida y os llama por su propheta Isaías: «Omnes sitientes venite ad aquas...». MUÑOZ DE LA CUEVA, J.: Noticias históricas de..., op. cit., p. 80.

${ }^{60}$ MORALES Y MARIN, J.L.: Diccionario de iconología y simbología. Madrid, 1984, p. 96.

${ }^{61}$ Su interés se centra no sólo en el epigrama sino también en el grabado que lo ilustra puesto que se ve un ciervo bebiendo en un río -»Corniger e latebris serpentem protrahit atrum cervus: et enectum protinus ore vorat. Tollere caede malos, ferroque domare nocentes; ludicis est virtus magna, ducisque boni: Qui finem statuit cupidinis, atque timoris: Et rectum parvo tramite monstrat iter. Culpa poena premit comes: immedicabile vulnus: Chirurgus ferro sanat, et igne, bonus. Parcere sicupit huic; iam pars sincera trahetur: Tristia supplicium crimina triste decet. Crimem ubique frequens, si laudi noxia iuncta est: Tunc virtus, et honosresque, salusque perit»- HENKEL, A. y SCHÖNE, A. (comps.): Emblemata: Handbuch zur Simbildkunst des XVI und XVII Jahrhunderts. Stuttagert, Metzler, 1967, p. 464.

${ }_{62} \ll$ El ciervo atrae âsi con el aliento,/De las ciegas cavernas donde mora,/La bivora, que le es mantenimiento,/Y saludable pasto, $y$ a la hora/Busca del agua viva el nacimiento,/con sollozos, y con llanto,/Mata el pecado, y qda limpio y santo». COVARRUBIAS, S. de: Emblemas morales. Madrid, Luís Sánchez, 1610. (Ed. facsímil Fundación Universitaria Española, Madrid, 1978, p. 90).
}

"CUADERNOS DE ESTUdIOS GALLEGOS", Tomo XLIII, Fascículo 108, Santiago 1996. 


\section{ALGUNAS OBRAS ANÓNIMAS}

Evangelistas. Catedral de Mondoñedo ${ }^{63}$. Se trata de cuatro tablas que donó en 1634 el obispo don Francisco de Villafañe, como adorno para la sacristía recientemente construida ${ }^{64}$.

Como es lógico, todas ellas forman un grupo homogéneo cuya procedencia debe relacionarse con un único autor anónimo. Sus rasgos más sobresalientes son: el tipo de composición empleada, su gama cromática -en la que dominan los tonos terrosos y rojizos y se detecta una cierta influencia veneciana- la individualización que consigue en los rostros y la iluminación de carácter tenebrista, que da lugar a unas figuras de acusada plasticidad.

San Mateo. (Lám. 12) Está sentado junto a una mesa, en una posición casi frontal, apoyándose sobre aquella. En su mano derecha sostiene un libro mientras que con la otra, escribe lo que le indica el ángel que está a sus espaldas y alarga el brazo hacia el libro.

Su composición está presidida por dos líneas diagonales que, al cruzarse, la equilibran. Por una parte, la descrita por el cuerpo del Evangelista y por otra, la que se proyecta al unir el brazo del ángel con el de Mateo y el libro. A pesar de todo, el equilibrio de masas que pretende conseguir el pintor fracasa al quedar el ángel constreñido en el ángulo superior izquierdo en una postura muy forzada.

${ }^{63}$ Autor: Anónimo. Cronología: Hacia 1632. Soporte: Tabla. Técnica: Oleo. Estado: Acumulación de suciedad; pérdida de policromía de forma puntual en las juntas del soporte. Medidas: 100 x $70 \mathrm{cms}$. Localización: MONDOÑEDO. Mondoñedo. Catedral. Sacristía. (Mondoñedo).

${ }^{64}$ Sobre la sacristía véase: CAL PARDO, E.: «Sacristía y custodia de la Catedral Basílica de Mondoñedo», Estudios Mindonienses, 3, (1987), pp. 549-570.

Este mismo autor, canónigo archivero de la Catedral de Mondoñedo, nos ha facilitado una información según la cual el obispo mencionado «dio quattro quadros de los quattro evangelistas a la $\mathrm{Fab}^{\mathrm{a}}$ desta $\mathrm{St}^{\mathrm{a}}$ Yglesia». ARCHIVO DE LA CATEDRAL DE MONDOÑEDO. Actas Capitulares 11 (1630-1645). 13 de enero de 1634, fol. 150.

Dicha información ratifica lo comentado por Florez -»las pinturas de los quatro evangelistas que adornan la Sacristía...»- Sanjurjo y Villaamil. FLOREZ, E.: España Sagrada. Theatro Geographico-Histórico de la Iglesia de España. XVIII. Madrid, Antonio Marín, 1764, p. 265; SANJURJO Y PARDO, R.: Los obispos de Mondoñedo. Lugo, 1854, p. 70; VILLAAMIL Y CASTRO, J.: La catedral de Mondoñedo..., op. cit., p. 53.

"CUADERNOS DE ESTUDIOS GALLEGOS", Tomo XLIII, Fascículo 108, Santiago 1996. 


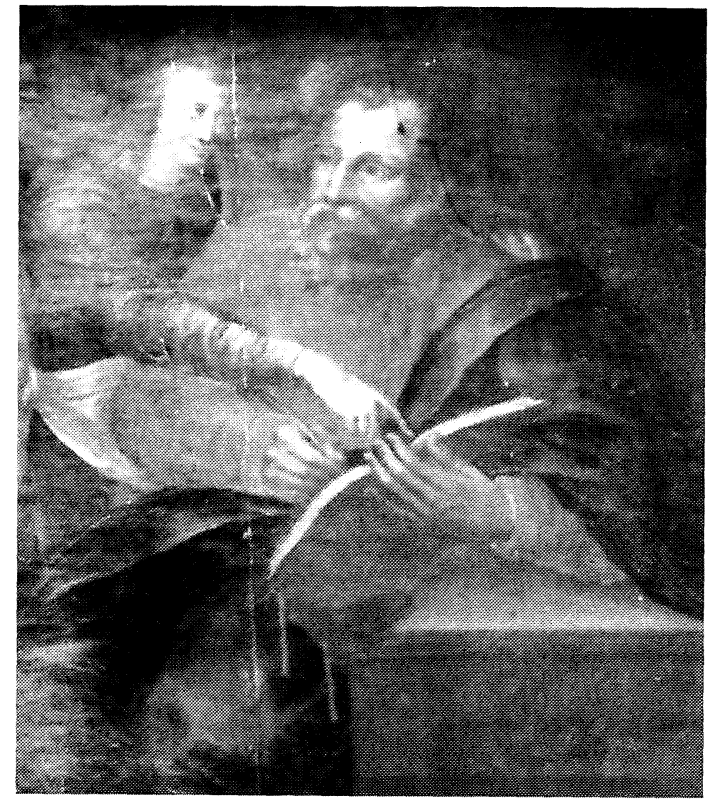

Lámina 12. San Mateo. Catedral de Mondoñedo.

San Marcos. (Lám. 13) Sentado también en posición frontal; la mesa está ahora situada de forma perpendicular al cuerpo del Evangelista quien, con gesto pensativo, se acoda sobre ella apoyando la cabeza en su mano.

A diferencia de San Mateo, San Marcos aparece con la cabeza cubierta por el manto, concentrado en la lectura; bajo su brazo izquierdo se puede ver la cabeza del león, su símbolo correspondiente.

San Lucas. (Lám. 14) La mesa -también presente en este cuadro, lo mismo que en el de San Juan- sirve como referencia espacial ya que se ha situado la figura tras ella.

Lucas está sentado, curiosamente no se presenta frontal sino en un marcado perfil que nos impide contemplar lo que está dibujando en una tabla que sostiene sobre sus rodillas con la mano izquierda. Evidentemente, el modelo está fuera del espacio representado lo que dota al cuadro de una mayor vitalidad.

Asimismo, San Lucas por su indumentaria -en especial por el gorro con que se cubre la cabeza- nos recuerda su condición de médico.

San Juan Evangelista. (Lám. 15) En una posición muy semejante a la figura anterior, si exceptuamos que éste se encuentra de pie y no sentado

"CUADERNOS DE ESTUDIOS GALLEGOS", Tomo XLIII, Fascículo 108, Santiago 1996. 


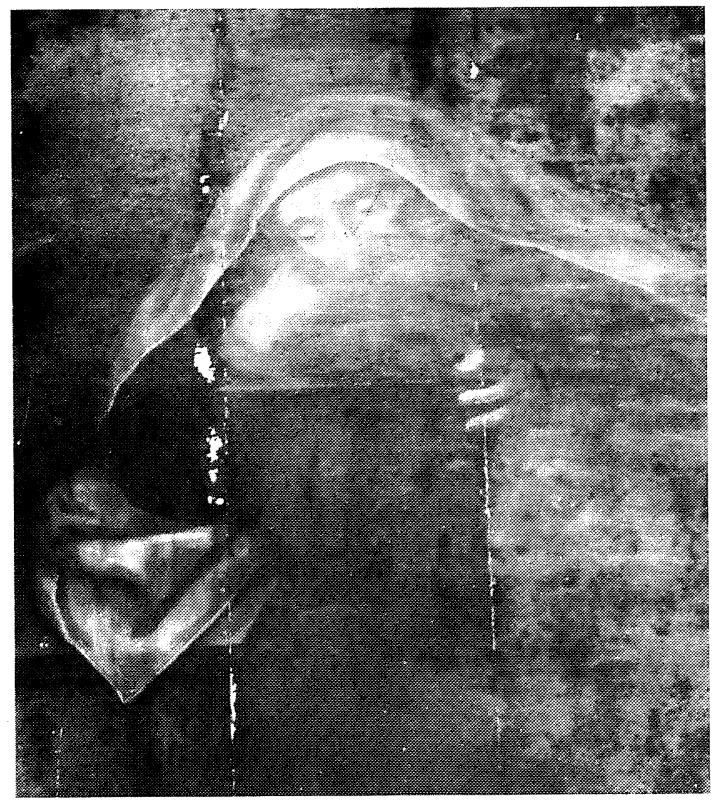

Lámina 13. San Marcos. Catedral de Mondoñedo.

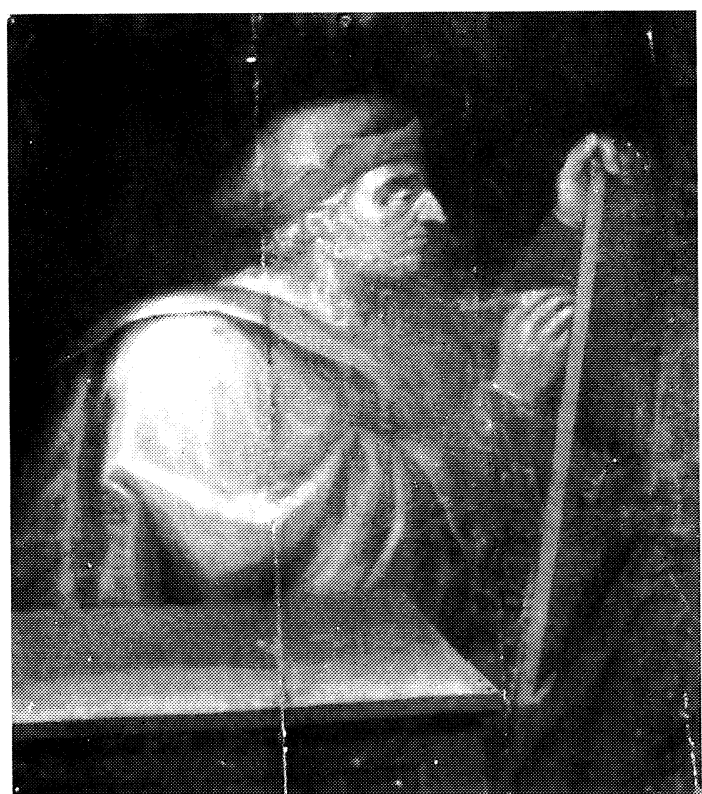

Lámina 14. San Lucas. Catedral de Mondoñedo. 


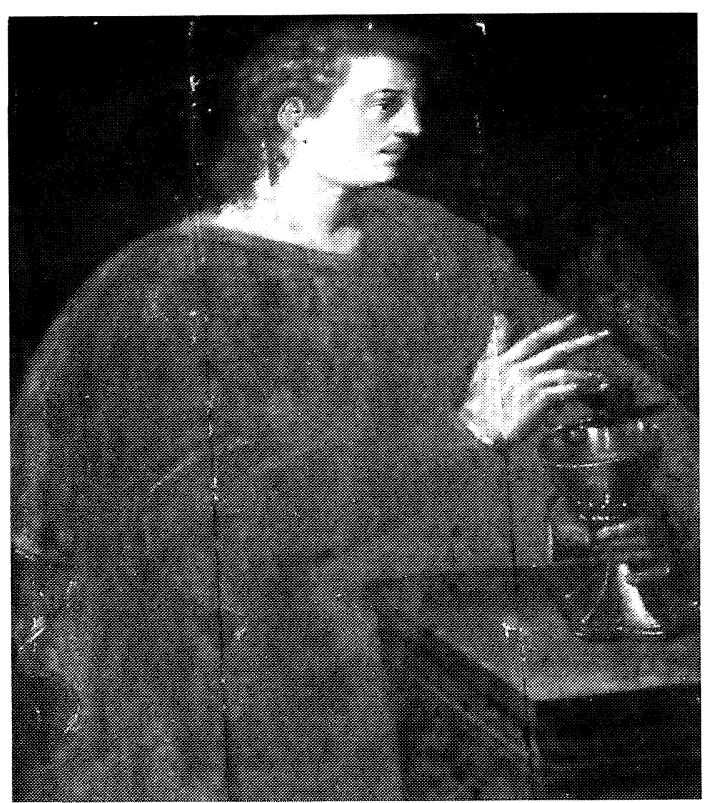

Lámina 15. San Juan Evangelista. Catedral de Móndoñedo.

tras una mesa, éste está impartiendo su bendición sobre un cáliz dorado del cual surge una serpiente alada -referencia al cáliz envenenado-. En su rostro se observa la presencia de un modelo tomado del natural cuya expresividad, sin embargo, no supera la de San Marcos.

Tras él, en la penumbra, podemos distinguir el águila que suele acompañar a este Evangelista.

Santo Domingo en Tolosa. Iglesia parroquial de Santa María de A Régoa de Monforte de Lemos ${ }^{65}$. (Lám. 16) La presencia de este lienzo en la antigua iglesia de San Jacinto no se debe extrañar puesto que es evidente la relación entre su tema y los primeros moradores de esta casa. Sin embargo, lo sorprendente, es el descubrir una obra de estas ca-

${ }^{65}$ Autor: Anónimo. Cronología: Segundo tercio del siglo XVII. Soporte: Lienzo. Técnica: Oleo. Estado: Sumamente oscurecido por la humedad y el polvo, presenta gran número de faltas así como huellas de agua y un intenso craquelado. Medidas: 240 x 391 cms. Localización: MONFORTE DE LEMOS. Monforte de Lemos. Iglesia parroquial de Santa María de A Régoa (Antiguo convento de San Jacinto). Coro. (Monforte de Lemos).

"CUADERNOS DE ESTUDIOS GALLEGOS", Tomo XLIII, Fascículo 108, Santiago 1996. 


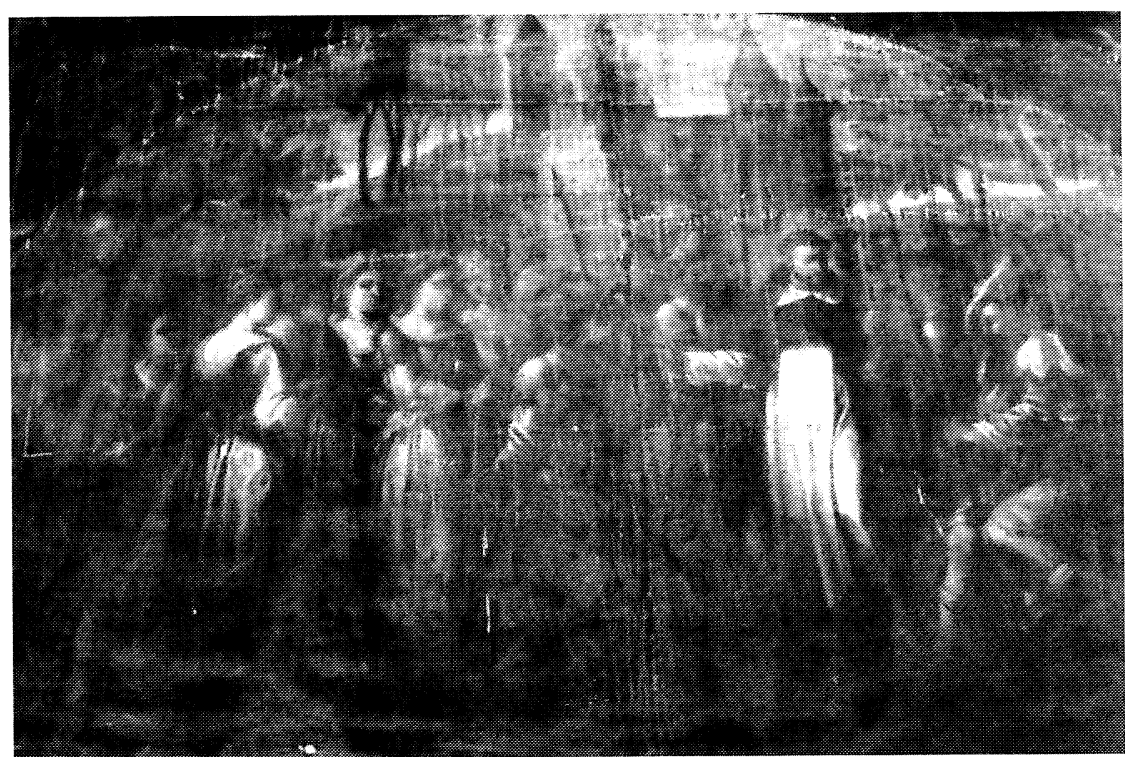

Lámina 16. Santo Domingo en Tolosa. Iglesia Parroquial de Santa María de A Régoa. Monforte de Lemos.

racterística -su origen foráneo, seguramente castellano, es incuestionable- en un convento de los considerados menores, de escasa importancia debido al número de sus miembros, que nunca superaría los dieciséis ${ }^{66}$.

Este hecho, junto al carácter de su fundación -antes de instalarse en Monforte bajo los auspicios de los condes de Lemos, don Pedro Fernández de Castro y su esposa doña Catalina de la Cerda y Sandoval ${ }^{67}$, éste tuvo su

${ }^{66}$ PARDO VILLAR, Au.: «El convento de San Jacinto de Monforte. (Notas históricas)», Boletín de la Real Academia Gallega, XX, 254, (1931), p. 143.

${ }^{67}$ Murguía comenta lo siguiente: «Fundó el primero el Lic. D. Alonso Ares, estableciéndolo en Ferreiros,... Mas como la dotación saliese incierta, trasladóle a Monforte el conde D. Pedro Fernández de Castro, dándole hacienda para doce religiosos de la orden de predicadores, y costeando la obra. Su esposa $\mathrm{D}^{\mathrm{a}}$. Catalina de la Cerda y Sandoval, le acudió también con una cuantiosa limosna, gracias á la cual recibió el necesario impulso la fábrica del edificio, la cual terminó en 1636». MURGUIA, M.: Galicia, op. cit., p. 1038, nota 1).

La historia de la comunidad ha sido estudiada por PITA ANDRADE, J.M.: Monforte de Lemos. V. Santiago de Compostela, 1952, pp. 58-60; VAZQUEZ, G.: Historia de Monforte y su tierra de Lemos. II. Pontevedra, 1971, pp. 271-280. Tanto el Poder del

"CUADERNOS DE ESTUDIOS GALLEGOS", Tomo XLIII, Fascículo 108, Santiago 1996. 
sede en Ferreiros, feligresía de San Martín de Pantón- ratifican su procedencia, que ahora tendremos que entender como una donación más que sus patronos realizan para el ennoblecimiento de la casa.

La forma del lienzo -a pesar de su formato cuadrangular- invita a pensar que éste debió estar destinado a algún lugar particular del convento ya que la escena se desarrolla dentro de un marco semicircular al cual debe adaptarse.

La composición es monumental, acusando en su presentación una excesiva rigidez al situarse todos los personajes que participan en ella en una única línea que es rota por la figura de Santo Domingo, centro focal de la tela, y por el caballero que, pensativo, aparece sentado a la derecha. Dicha rigidez es la causa del sentido teatral que posee la escena, cerrada por un fondo telón compuesto por un paisaje boscoso en el cual se sitúa una iglesia. De igual modo debemos entender las lanzas de los soldados que forman parte del «coro» de actores.

La obra responde a los rasgos específicos del siglo XVII, de los años finales de su segundo tercio. Se puede observar como se ha abandonado el realismo exacerbado -practicado por la primera generación barroca- en beneficio de una idealización mayor que va acompañada de un enriquecimiento de su gama cromática, de una suavización de los contrastes lumínicos, aunque sea la luz la que modele las figuras y los contraluces juegen un papel primordial dentro del cuadro, y de una ejecución más rápida y suelta. A pesar de ello, todavía es posible encontrarse con características heredadas de las décadas anteriores como el blanco luminoso del hábito de santo Domingo o su plegado, de intensa plasticidad.

La escena que se nos presenta es de difícil interpretación al no ser uno de los temas más habituales dentro de la iconografía dominicana. Seguramente en él se tenga que ver, simplemente, un episodio de la vida de Santo Domingo ${ }^{68}$, sin que, por ello, tenga que haber pertenecido a una

provincial dominico al prior de Pantón, para asistir a las escrituras de traslado del convento de Pantón a Monforte de Lemos como la escritura de fundación del monasterio de San Jacinto de Monforte de Lemos, hecha por la Condesa de Lemos, Doña Catalina de la Cerda, han sido publicados por VAZQUEZ FERNANDEZ, L.: Documentos da Historia de Monforte no século de ouro. Lugo, 1991, pp. 249, 270-273.

${ }^{68}$ Mâle menciona la existencia de series dedicadas a la vida del Santo Fundador que destacan por su minuciosidad, incluso comenta la existencia de colecciones de grabados publicados por la Orden que la narran. MALE, E.: El Barroco..., op. cit., p. 383, nota 156. 
serie de la que sólo se conservaría este cuadro ${ }^{69}$.

En este sentido la lectura del lienzo reviste cierta complejidad. Está claro que se trata de un momento de la predicación de Santo Domingo, identificado a través de la estrella situada sobre su frente y el crucifijo que sostiene en su mano izquierda; la dificultad surge al no poder relacionarlo con algún acontecimiento particular de los que se narran en su vida ${ }^{70}$ ya que en torno a él -aparte del caballero que hemos mencionado con anterioridad- se reunen un grupo de damas y soldados. Quizás por ello, sea conveniente intentar, no identificar el episodio, sino los personajes que lo componen y la relación que los une al Santo.

De este modo, las mujeres que aparecen a su derecha -grupo en el cual, además de errores compositivos crasos, se introducen aciertos como el de que algunas de ellas invadan el espacio del espectador con su mirada- se debe entender como una referencia a aquellas mujeres que redimió durante su predicación contra los herejes de Albi -»Havia à la sazón grandíssima necesidad, y pobreza en aquellas provincias, à causa del nuevo levantamiento de tierra: crecio tanto, que algunas personas nobles vendían a sus hijas, y las daban à criar a los Herejes, compelidos de la extrema necesidad que passaban. Para reparo de este daño, y del estrago, que el demonio hacía, procuró Santo Domingo, que en un sitio muy a propósito para ello, que se llama el Pruliano, entre Carcasona y Tolosa, se hiciesse un Monasterio para recoger la gente noble y necessitada, donde en breve tiempo se encerraron gran número de doncellas con una cierta forma de vivir, que él les dió...» ${ }^{71}$.

Por su parte, la gente armada y el caballero tendrían que ser el ejército que el Santo, como inquisidor, levantó contra los herejes junto a su capitán, el conde Simón de Monfort -»Y haviendole el papa mandado tomar

\footnotetext{
${ }^{69}$ Valiñas Sampedro menciona la existencia de otro lienzo de menores proporciones, también localizado en el coro de la iglesia, de tema dominicano. VALIÑAS SAMPEDRO, E.: «Monforte de Lemos», en Inventario Artístico de Lugo y su provincia. IV. Madrid, 1980, p. 227.

${ }^{70}$ LOPEZ, J.: Historia de los Santos canonizados y beatificados de la orden de predicadores. Valladolid, Juan de Rueda, 1622, pp. 1-197; VORAGINE, J. della: La Leyenda Dorada..., op. cit., I, pp. 440-456.

${ }^{71}$ RIBADENEYRA, P. de: Flos Sanctorum, de las vidas de los Santos.... II. Madrid, Joachim Ibarra, 1761, p. 468.
}

"CUADERNOS DE ESTUDIOS GALLEGOS", Tomo XLIII, Fascículo 108, Santiago 1996. 
el Oficio de Inquisidor contra los Hereges, él lo exercitó con grande autoridad, usando de todas las armas espirituales para reducirlos, castigarlos, y reprimirlos. Y juntándose después los temporales de los Principes Cathólicos, que hicieron un grande y lucido Exército...» ${ }^{72}$.

Con estos datos, y atendiendo a la actitud apesadumbrada del conde y a los gestos de las damas y los soldados, se podría interpretar, siempre con los reparos debidos, este episodio como el momento de la despedida de Santo Tomás, que coincide con la fundación de la Orden: «Y San Pedro le dió un báculo en la mano, y San Pablo un libro abierto, diciendo: Toma tu camino, y vete sin tardanza à hacer el oficio que Dios demanda: predicad el Evangelio tú, y los tuyos; pues para esso os ha escogido el Señor. Y acabadas estas palabras, le pareció, que veía todos sus Discípulos, Hijos, y Compañeros, que de dos en dos se iban predicando por el mundo. Esta revelación recreó también mucho el espíritu de Santo Domingo, y le dió priessa para que tomando sus Despachos, se partiesse luego de Roma para Tolosa, adonde halló sus Hijos; y comunicándoles la concessión de la Sede Apostólica, que trahía, y la vocación à que Dios le llamaba, los exhortó para que todos se aparejassen á ser de veras Predicadores Evangélicos, y peregrinar por todo el mundo, à imitación de los Apóstoles, y à dar la vida por el Señor. Y puesto caso que el conde Simón de Monfort, y el Arzobispo de Narbona, y el Obispo de Tolosa, y otros grandes personajes sentían mucho, que aquellos Padres se fuessen de sus tierras, y con razones humanas se lo quiessen estorvar; más à todos respondía el Santo Varón lleno de espíritu del Cielo y decía: Ya yo sé lo que en esta parte tengo que hacer: ninguno me estorve; porque yo soy madando, y Dios ha de ser obedecido.... $\gg^{73}$.

Si esta lectura que ahora proponemos fuera la adecuada, nos encontraríamos con que de ella se podrían extrapolar dos consecuencias que ratificarían lo expuesto con anterioridad. En primer lugar, se justificaría la presencia del cuadro al referirse a uno de los momentos cruciales de la Orden: el comienzo de su verdadera labor evangelizadora; en segundo lugar, la coincidencia entre el nombre del Conde, Simón de Monfort, y la

\footnotetext{
${ }^{72}$ RIBADENEYRA, P. de: Flos Sanctorum..., op. cit., II, p. 469.

${ }^{73}$ RIBADENEYRA, P. de: Flos Sanctorum..., op. cit., II, p. 471.
} 
villa de Monforte serviría para rendirle homenaje a aquellos que habían sido los verdaderos fundadores del convento ${ }^{74}$.

\section{UN EJEMPLO FLAMENCO}

Este conjunto de trece tablas conservadas en el Museo das Mariñas de Betanzos, restaurado en 1983, cuenta con un estudio monográfico realizado por Beatriz Martínez-Barbeito Manovel ${ }^{75}$. En él, dicha autora prueba, sin lugar a dudas, su relación con la escuela de Rubens y su procedencia flamenca.

Apostolado. Museo Municipal de Betanzos ${ }^{76}$. Estas obras, de lo más sobresaliente que se conserva en el patrimonio pictórico gallego del siglo XVII, proceden de la donación que don Antonio Sánchez de Taibo y Vilouzás y doña Estefanía de Valencia y Guzmán realizan en el momento de la fundación del Hospital de San Antonio de Betanzos ${ }^{77}$. Su memoria histórica ha perdurado bajo la denominación de «Pintura de Roma», como se la califica en los inventarios del Hospital -tal vez por su calidad más que por su temática religiosa-, o a través de escritos como los de Martínez

\footnotetext{
${ }^{74}$ «Desde un principio fue doña Catalina de la Cerda y Sandoval valedora inestimable en todas aquellas gestiones y para acelerar la construcción del edificio, donando una importante cantidad por escritura otorgada ante el escribano de la villa de Madrid, Juan de Santillana, en 1 de febrero de 1623». VAZQUEZ, G.: Historia de Monforte..., op. cit., II, p. 273.

${ }^{75}$ MARTINEZ-BARBEITO MANOVEL, B.: «Restauración del Apostolado del Hospital de San Antonio de Padua de Betanzos», Anuario Brigantino, 10, (1983), pp. 127 144.

${ }^{76}$ Autor: Escuela flamenca. Cronología: Tercer cuarto del siglo XVII. Soporte: Tabla. Técnica: Oleo. Estado: Bueno. Ha sido restaurado recientemente. Medidas: 92 x 65 cms. c./u. Localización: BETANZOS. Betanzos. Museo Municipal. (Proceden del Hospital de San Antonio de Padua de esta misma ciudad).

${ }^{77}$ Tal como se dice en la escritura fundacional, este se crea para «... hacer agradable servicio a Dios nuestro Señor... y alivio de la dicha ciudad, refugio y amparo y conveniencia de sus vecinos y de los de su jurisdicción y de los peregrinos que pasaran por ella...». (A.M.B.) Archivo Municipal de Betanzos. (A.H.S.A.P.) Archivo del Hospital de San Antonio de Padua. Acta de fundación. f. 44v-45r. Dicho documento iba acompañado por la donación de múltiples efectos personales.
}

"CUADERNOS DE ESTUDIOS GALLEGOS", Tomo XLIII, Fascículo 108, Santiago 1996. 
Santiso $^{78}$ y Carré Aldao ${ }^{79}$.

Su procedencia -hasta hace pocos años incierta- parece apuntar, según los datos aportados por Martínez-Barbeito Manovel, hacia Flandes donde Don Antonio, en su condición de caballero del Consejo y Contaduría Mayor de Hacienda del rey Carlos II, debió desarrollar algún cargo político; por otra parte, en la cara oculta de cada tabla aparecen, grabados al fuego, cuatro marcas que han sido identificadas como el escudo de Amberes y el anagrama del artesano o taller que cortó y acondicionó la madera $^{80}$; por último, el roble -material utilizado- vuelve a incidir, aunque no de una forma rotunda, sobre su origen flamenco ${ }^{81}$.

La elaboración técnica de las obras ratificará lo dicho hasta el momento; «la madera es similar y está preparada con una capa igual a base de yeso y cola sobre la cual aparece una imprimación parda aplicada a brochazos largos e irregulares. El efecto así es menos monótono que con las bases oscuras y uniformes usadas por influencia italiana y tiene también la ventaja de que al ser traslúcida y estar aplicada irregularmente deja brillar a su través la base de yeso blanco. La imprimación tiene un papel importantísimo en los efectos del color y en especial en la carnación, donde se ha invertido el procedimiento tradicional. Las luces son espesas y opacas para cubrir la base, mientras que las sombras son restregadas, finas y traslúcidas. El efecto óptico es frío y nacarado en las sombras y cálido en las luces. Esta elaboración de volúmenes a base de modular tonos calientes y fríos se consigue tan sólo controlando el espesor de

\footnotetext{
${ }^{78}$ «Dio a este objeto el edificio que todavía subsiste en el cantón de San Roque, y algunos efectos entre los que se hallan doce hermosos cuadros con los bustos de los doce Apóstoles, obra de gran mérito y la mejor que en el arte pictórico tiene Betanzos, según dictamen de persona perita». MARTINEZ SANTISO, M.: Historia de la ciudad de Betanzos. 1892. (Ed. facsímil, A Coruña, 1987, p. 345).

${ }^{79}$ «...Dándole además, entre otros efectos, doce hermosos cuadros con los bustos de los doce apóstoles, que son las mejores obras pictóricas con que cuenta Betanzos...». CARRE ALDAO, E.: Provincia de La Coruña, en Geografía General del Reino de Galicia, dirigida por F. Carreras Candi, A Coruña, 1930 (Ed. facsímil, A Coruña, 1987, IV, V, VI, VII, p. 797).

${ }^{80}$ «En el reverso de los retratos de los apóstoles hay unas marcas grabadas a fuego». BOUZA, B. da: «Betanzos», Gran Enciclopedia Gallega, III, p. 230; MARTINEZBARBEITO MANOVEL, B.: «Restauración del Apostolado...», op. cit., pp. 129-132.

${ }^{81}$ Este razonamiento se puede seguir más ampliamente en: MARTINEZ-BARBEITO MANOVEL, B.: «Restauración del Apostolado...», op. cit., pp. 129-132.
}

"CUADERNOS DE ESTUdiOS GALLEGOS", Tomo XLIII, Fascículo 108, Santiago 1996. 
la pintura. Si la técnica pictórica se encuentra íntimamente ligada con la intencionalidad e inspiración artística se puede afirmar también que avanza paralelamente a otra que nace para que ésta pueda prevalecer en el tiempo con su verdadera composición y sentido» ${ }^{82}$.

Una particularidad más, revaloriza esta serie; es una copia íntegra del llamado Apostolado de Lerma del Museo del Prado pintado por Rubens en torno a 1612-1614, después de su regreso a Amberes ${ }^{83}$. Nos encontramos, por lo tanto, ante una de esas copias que, realizadas ya dentro de su taller y con su intervención directa, y efectuadas por sus discípulos o, simplemente, como réplicas, circulaban por toda Europa ${ }^{84}$. El hecho de que ésta fuera adquirida por los fundadores del Hospital de San Antonio no es extraño ya que la difusión que tuvieron las obras de Rubens -a través de grabados y copias en cobre de artesanos menores- terminó por trastocar los gustos sobrios, y un tanto sombríos de una tradición tenebrista, por el colorido, la composición y el dinamismo de las obras del maestro flamenco, hasta constituir este fenómeno una verdadera moda ${ }^{85}$.

${ }^{82}$ MARTINEZ-BARBEITO MANOVEL, B.: «Restauración del Apostolado...», op. cit., pp. 133-134.

${ }^{83}$ En un principio se dató como de 1603, siendo Norris -NORRIS, Ch.: The Burlington Magazine, CXV, (1953), pp. 107-108-, Warnke-WARNKE, M.: Kommentare zu Rubens, 1965, p. 76, nota 32-, Larsen - LARSEN,E.: «Three lesser known works by Rubens», Koninkligk Museum Jaarboek, Amberes, 1969, p. 39- y Müller-Hofstede -MÜLLERHOFSTEDE, J.: «Eine kreidestudie von Rubens für den Kreuzaufrich-tongsaltar», Pantheon, XXV, (1967), p. 39- quienes retrasaron su realización a la segunda década del XVII (1612-1613). (Cit. DIAZ PADRON, M.: Museo del Prado: Catálogo de pinturas. Escuela Flamenca, siglo XVII. Madrid, 1975, pp. 236-243, láms. 166-169).

Vosters, más tarde, la retasa a 1614. VOSTERS, S. von: Rubens y España. Estudio artístico-literario sobre la estética del Barroco. Madrid, 1990, pp. 41-42.

${ }^{84}$ BODART, D.: Rubens. Barcelona, 1981, pp. 59-63. En una carta dirigida, el 28 de abril de 1618, a Sir Dudley Carlton, embajador inglés en La Haya, Rubens le ofrece «doce apóstoles con un Cristo hecho por mis discípulos del original que tiene el Duque de Lerma de mi mano...», lo que indica que, lo mismo que en las reproducciones múltiples actuales, lo que se paga es la creación propia, la idea.

${ }^{85}$ «Así, el artista y la obra de arte flamenco, sólo por el hecho de su procedencia, gozaba de una especial estimación; en la mayoría de los casos muy superior a la que le correspondía por su auténtico valor y calidad. Bien expresivo de esta preferencia en la literatura del siglo XVII es el hecho de cómo quedó como expresión ponderativa de todo lo bello el comprarlo como un lienzo de Flandes». OROZCO DIAZ, E.: «Juan de Sevilla y la influencia flamenca en la pintura española del Barroco», Goya, 27, (1958), p. 145; PEREZ SANCHEZ, A.E.: «Rubens y la pintura barroca española», Goya, 140-141, (1977), p. 86.

"CUADERNOS DE ESTUDIOS GALLEGOS", Tomo XLIII, Fascículo 108, Santiago 1996. 
En conjunto, se trata de la representación de Cristo y sus doce Apóstoles sobre un fondo neutro claro, en busto largo que incluye, en algunos casos, las manos; en todos ellos, lo mismo que en los del Prado, se busca su individualización, tanto de rostro como de gesto -medido y equilibrado-, la penetración anímica y el estudio psicológico de los tipos, y su sentido escultórico y monumental, logrado a través de contrastes lumínicos intensos, producto de una luz dirigida de origen caravaggesco ${ }^{86}$.

No obstante, como sucede habitualmente, no existe una correspondencia absoluta entre las tablas del Prado y las de Betanzos; las variaciones se deben tanto a la flexibilidad con que los atributos de cada uno de los apóstoles pueden, en algunos casos ser utilizados, como a la fuente gráfica a la que el artista haya podido recurrir ${ }^{87}$.

San Pedro ${ }^{88}$. (Láms. 17-18) Esta tabla se corresponde con su homónima del Museo del Prado catalogada con el número 1646. Aunque como en aquella, mantiene la cabeza y la mirada elevada hacia el cielo, el gesto de sus manos ha cambiado, lo mismo que su rostro. En el cuadro que nos ocupa, su cara, aún respetando sus rasgos fisionómicos generales, es mucho más ancha, menos escuálida, y su barba -más corta y recta- oculta un fuerte mentón. A diferencia de la madrileña, en la cual San Pedro va vestido con un manto sobre el que luce el palio papal, en la de Betanzos lleva una sencilla túnica azulada, cerrada a la altura del pecho por un cordón, y un manto dorado que le desciende por su hombro izquierdo y se recoge bajo el brazo del mismo lado, viéndose, unicamente, la mano en la que

${ }^{86}$ Véase LAFUENTE FERRARI, E.: El Prado. La pintura nórdica. Madrid, 1977, pp. 196-197; STEPANOW, G.: Rubens. Barcelona, 1958, pp. XVII-XVIII; BODART, D.: Rubens..., op. cit., p. 67.

${ }^{87}$ El hecho de que todas las tablas del Hospital de San Antonio de Padua lleven el nombre del Apóstol con el que se corresponde, aún no siendo un dato decisivo y tratándose de nombres escritos con posterioridad a su ejecución, ya en España ya en el momento de su adquisición, puede responder a alguna de las series de dibujos existentes -Nicolas Ryckmans, Peter Issellburg, G. Donk o Gaspar Huberti-. Por ejemplo, en América esta serie fue conocida a través de los dibujos de Ryckmans. Cfr. SEBASTIAN, S.: El Barroco Iberoamericano. Mensaje iconográfico. Madrid, 1990, p. 190.

${ }^{88}$ (S. PEDRO). Sobre el apostolado del Museo del Prado véase DIAZ PADRON, M.: Museo del Prado: Catálogo de pinturas. Escuela Flamenca, siglo XVII. Madrid, 1975, pp. 236-243, láms. 166-169.

"CUADERNOS DE ESTUDIOS GALLEGOS", Tomo XLIII, Fascículo 108, Santiago 1996. 


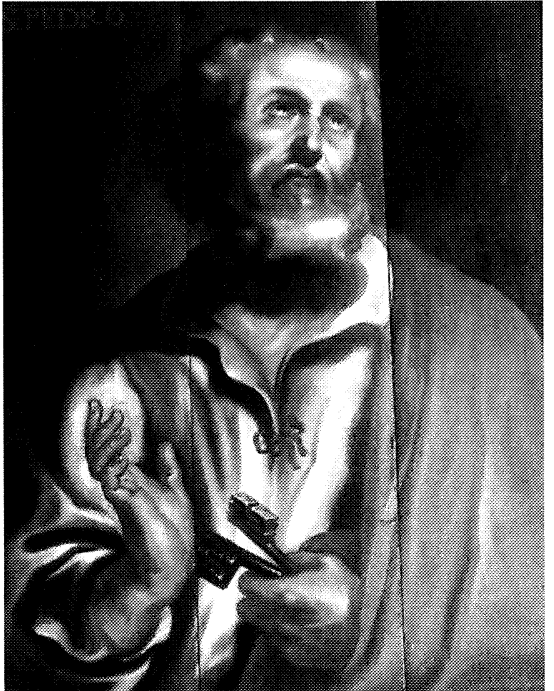

Lámina 17. San Pedro. Museo das Mariñas. Betanzos.

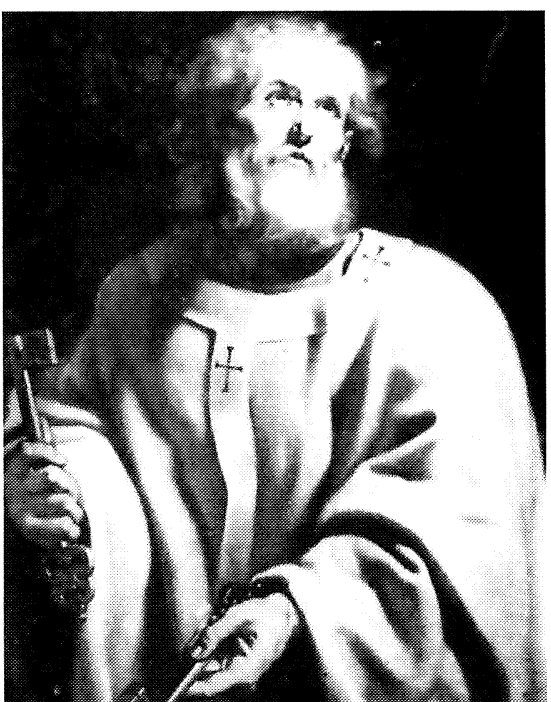

Lámina 18. San Pedro. P.P. Rubens. Museo del Prado. Madrid. Cat. 1646.

sostiene las dos llaves, una de plata y la otra de oro ${ }^{89}$.

San Juan Evangelista ${ }^{90}$. (Láms. 19-20) En este caso aparece representado como Apóstol, con túnica grisácea y manto rojo y un cáliz en su mano izquierda ${ }^{91}$. La figura ha perdido la gracia y elegancia que poseía en

${ }^{89}$ El color de su manto simboliza la Fe Revelada. Curiosamente Ayala, al hablar de las ropas que deben mostrar Cristo y los Apóstoles considera «ridículo y falso» representarlos con «brillantez y variedad de colores... porque, bien que no sepamos con certeza de que color eran los vestidos de los Judíos, con todo tengo por mucho mas probable, que usaran principalmente de dos; á saber del blanco y del obscuro». INTERIAN DE AYALA, J. Fr.: Pictor Christianus Eruditus..., op. cit., I, p. 72).

Reau define el valor simbólico de las llaves de San Pedro diciendo: «...mais il y en a géneralment deux, l'une d'ore et l'autre d'argent, clefs du ciel et de la terre qui symbolisent le pouvoir de lier et de délier, d'absoudre et d'excommunier que le Christ avait conféré au Prince dos Apôstres...». REAU, L.: Iconographie de L'Art Chrétien. Iconographie des saints. París, 1959, III-3, p. 1083.

${ }^{90}$ (S.JVANEVAN/GELISTA) Se corresponde con el número 1647 del catálogo del Museo del Prado.

${ }_{91}$ «Pintanle con el Cáliz en la mano, asi por las palabras que dixo Christo: De verdad bebereis mi Cáliz; como tambien porque, conforme escribe S. Isidoro, habiendo bebido veneno, no le hizo daño, según la promesa de Jesu-Christo: si bebiere alguna cosa envenenada, no les hará daño. Añaden además, para significar la qualidad de la bebida mortal, á una pequeña serpiente, ó vibora saliendo del Cáliz». INTERIAN DE AYALA, J. Fr.: Pictor Christianus Eruditus..., op. cit., II, p. 471.

"CUADERNOS DE ESTUDIOS GALLEGOS", Tomo XLIII, Fascículo 108, Santiago 1996. 


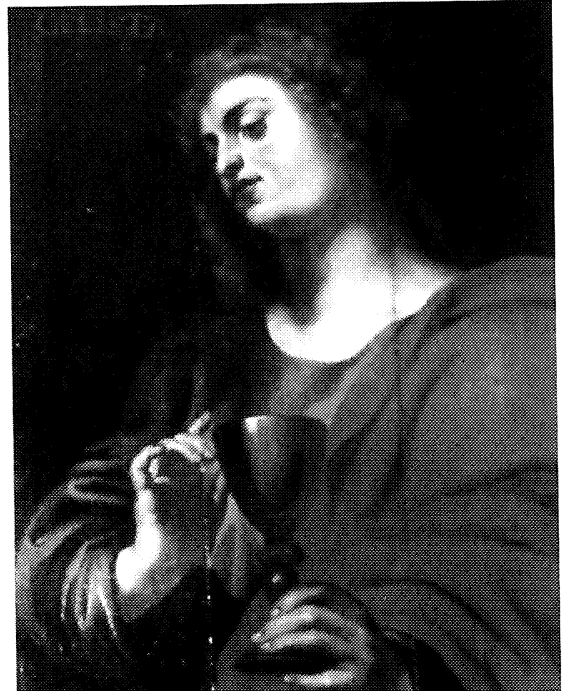

Lámina 19. San Juan Evangelista. Museo das Mariñas. Betanzos.

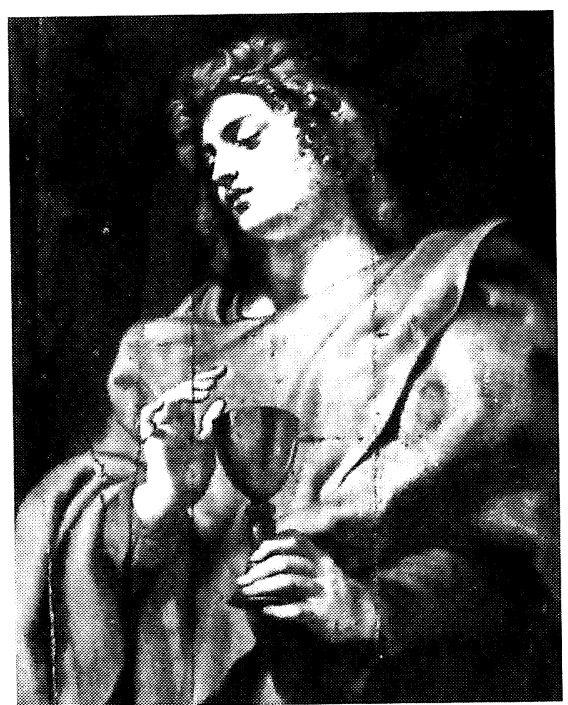

Lámina 20. San Juan Evangelista. P.P. Rubens. Museo del Prado. Madrid. Cat. 1647.

el Apostolado de Lerma; su cara abotargada, un tanto enfermiza, y la difícil organicidad de su cuello, grueso y largo, hacen que «el recuerdo de los prototipos boloñeses, próximos a Carracci ${ }^{92} »$ sea sustituido por una presencia ambigua y casi malsana.

Santiago el Mayor ${ }^{93}$. (Láms. 21-22) Se trata de una copia textual de la tabla del Prado; su indumentaria de peregrino, el modo de sostener el bordón y el libro, su cabeza, que se recorta sobre un claro del fondo, y su mirada franca y directa, la convierten en uno de los mejores retratos de este Apostolado de Betanzos.

San Andrés ${ }^{94}$. (Láms. 23-24) El Santo, de perfil, apoya su brazo sobre la cruz en aspa de su martirio. Aunque sigue el modelo del Prado -la cabeza la gira hacia su derecha, fuera del ámbito de la obra, su barba es larga y partida, lo que de modo figurado se llama barba de chivo, y mues-

${ }^{92}$ DIAZ PADRON, M.: Museo del Prado: Catálogo de pinturas..., op. cit., p. 238.

${ }_{93}$ (S.TIAGO/MAIOR). Se corresponde con el número 1648 del catálogo del Museo del Prado.

${ }^{94}$ (S.ANDRES). Se corresponde con el número 1649 del catálogo del Museo del Prado.

"CUADERNOS DE ESTUdIOS GALLEGOS", Tomo XLIII, Fascículo 108, Santiago 1996. 


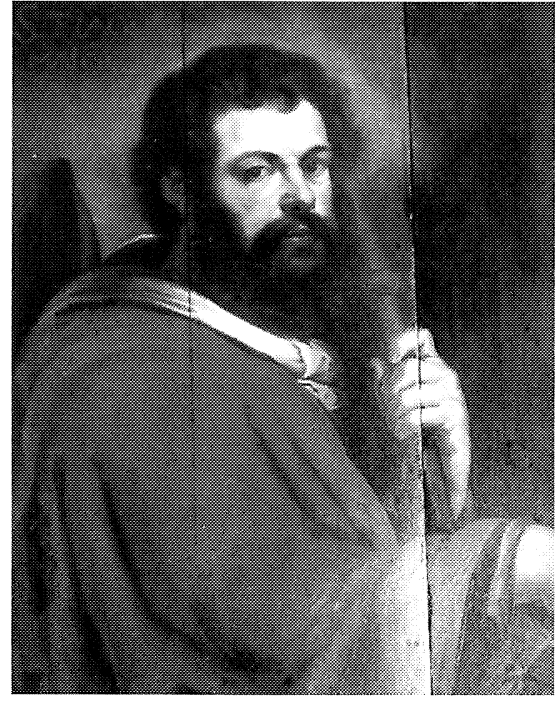

Lámina 21. Santiago el mayor. Museo das Mariñas. Betanzos.

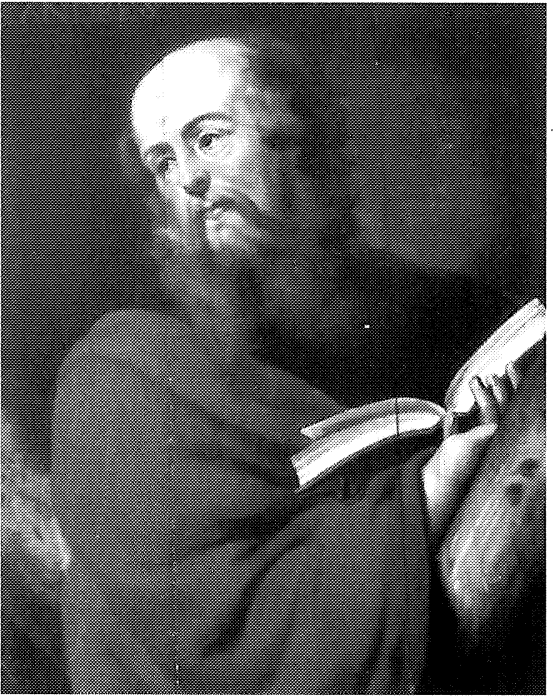

Lámina 23. San Andrés. Museo das Mariñas. Betanzos.

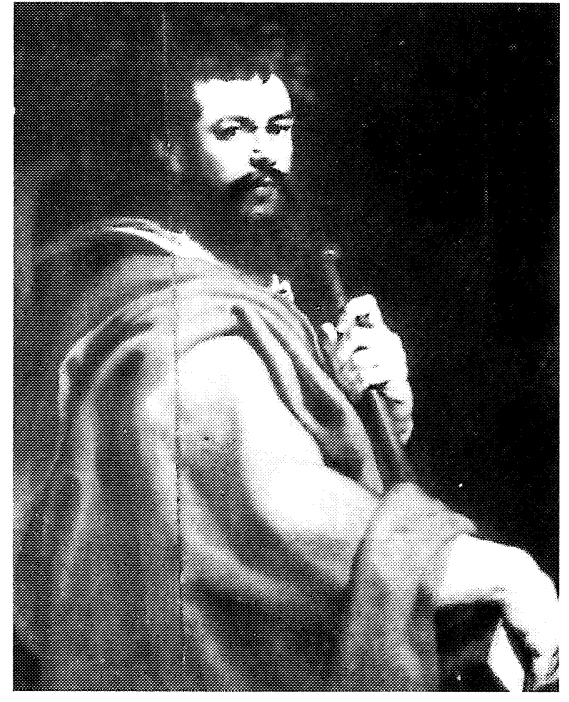

Lámina 22. Santiago el mayor. P.P. Rubens. Museo del Prado. Madrid. Cat. 1648.

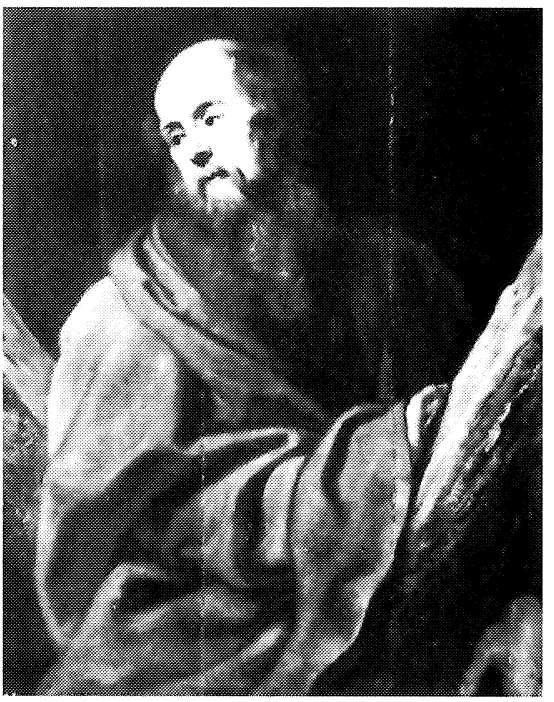

Lámina 24. San Andrés. P.P. Rubens. Museo del Prado. Madrid. Ct. 1649. 
tra una acusada calvicie-, el artista ha añadido un libro abierto al que el Apóstol no presta atención.

San Felipe ${ }^{95}$. (Láms. 25-26) El Santo, de perfil y girado, dándonos practicamente la espalda, está concentrado en la lectura de un gran libro. Se nos presenta como un anciano de pelo cano, piel tostada y mirada cansada, con los ojos entreabiertos. La ausencia de algún atributo que lo distinga ha sido la causa de que, en el caso de la tabla de la serie del duque de Lerma, haya sido identificado tanto con San Judas Tadeo como con San Simón, atribución aceptada en la actualidad ${ }^{96}$.

Santiago el Menor ${ }^{97}$. (Láms. 27-28) Este Apóstol, conocido también como Santiago Alfeo o Santiago, hermano del Señor ${ }^{98}$, fue pintado de perfil, con larga barba y cabellera cana. De nuevo, la intensidad de su mirada y lo adecuado del gesto -dirige su mano derecha hacia el pecho, en ese ademán tan habitual que alude al corazón- hace de este cuadro otra de las piezas más logradas de toda la serie.

Si lo comparamos con el San Felipe del Museo del Prado se puede observar como el único cambio que se aprecia es la sustitución del instrumento del martirio correspondiente, en el caso de San Felipe la cruz, en el de Santiago el garrote.

San Bartolome ${ }^{99}$. (Láms. 29-30) La descripción fisionómica que el pintor lleva a cabo en este caso es de las más sobresalientes: un anciano de cabellos blancos, calvo, y de ojos hundidos, que vuelve su mirada hacia el cielo. En éstos se refleja, no la súplica, sino la callada aceptación y

${ }^{95}$ (S.PHELIPE). Se corresponde con el número 1655 del catálogo del Museo del Prado.

${ }^{96}$ Ayala al comentar las «armas» de San Felipe dice: «Finalmente, el que le pinten con un libro, es muy bien hecho; pues á todos los Apóstoles les conviene esta noble divisa, por haber sido los que anuncian a las Gentes la doctrina del Evangelio...». INTERIAN DE AYALA, J. Fr.: Pictor Christianus Eruditus..., op. cit., II, 182.

${ }^{97}$ (STIAGOME/NOR). Se corresponde con el número 1650 del catálogo del Museo del Prado.

${ }^{98}$ «Digamos, finalmente, que el sobrenombre de hermano del Señor, dado a Santiago, pudo obedecer a una de estas dos cosas: a que Santiago y Jesús fuesen parientes próximos, como comunmente se cree...; o a que Santiago descollara sobre los demás apóstoles por las excelencias de sus virtudes y por la semejanza moral con Jesucristo». VORAGINE, S. de la: La leyenda dorada. Madrid, 1982, p. 280.

${ }^{99}$ (S.BARTHOLO/ME). Se corresponde con el número 1652 del catálogo del Museo del Prado.

"CUADERNOS DE ESTUDIOS GALLEGOS", Tomo XLIII, Fascículo 108, Santiago 1996. 


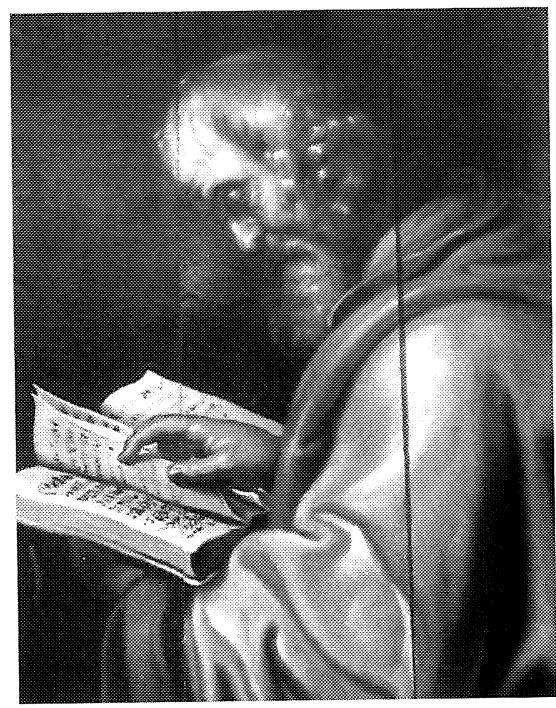

Lámina 25. San Felipe.

Museo das Mariñas. Betanzos.

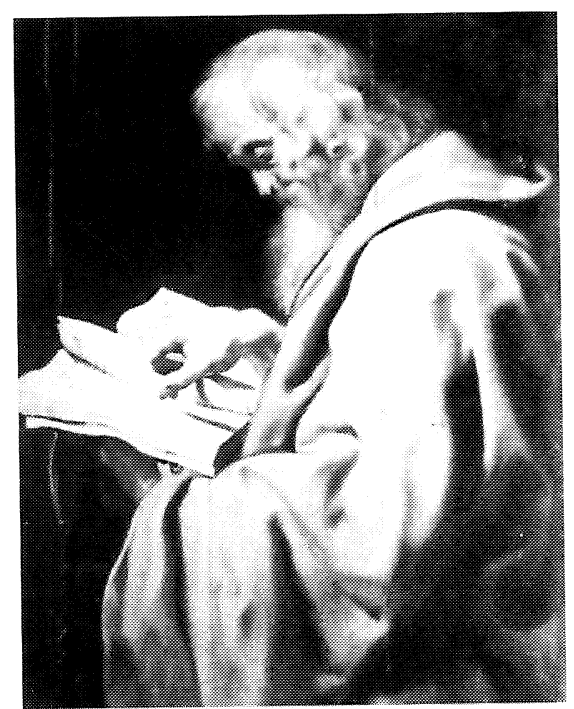

Lámina 26. San Simón. P.P. Rubens. Museo del Prado. Madrid. Ct. 1655.

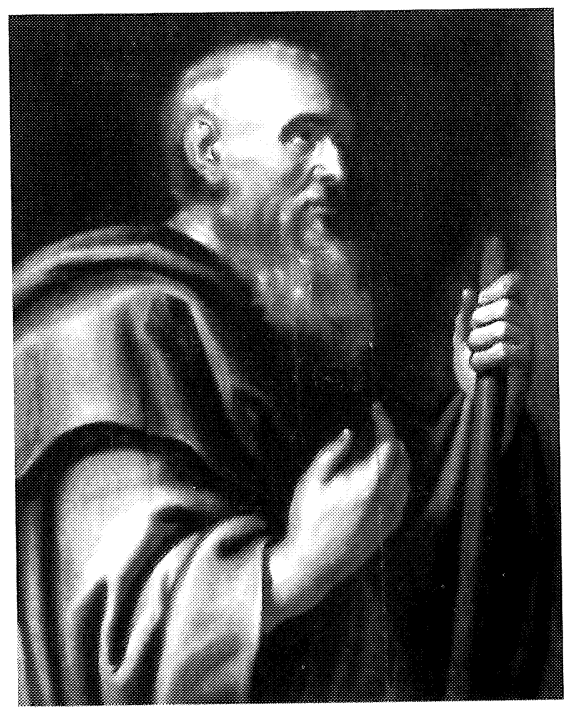

Lámina 27. Santiago el menor. Museo das Mariñas. Betanzos.

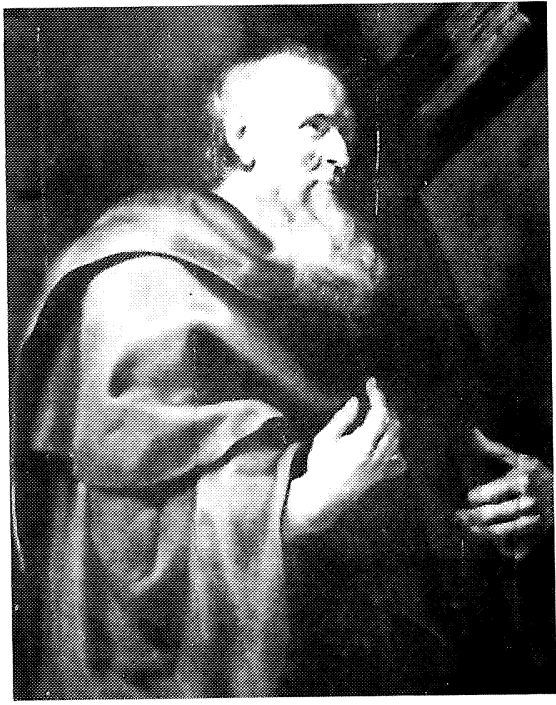

Lámina 28. San Felipe. P.P. Rubens. Museo del Prado. Madrid. 


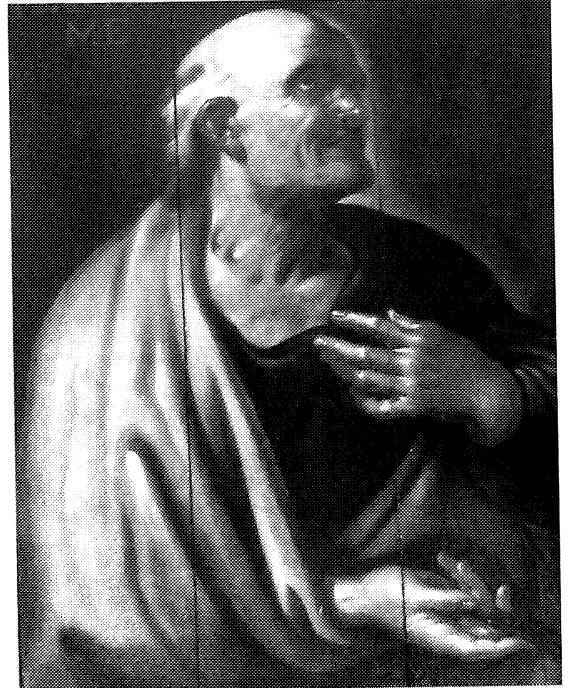

Lámina 29. San Bartolomé. Museo das Mariñas. Betanzos.

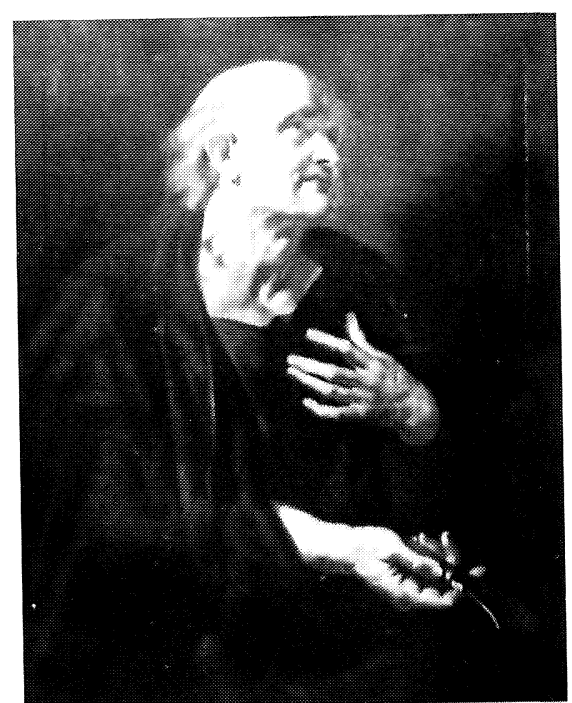

Lámina 30. San Bartolomé. P.P. Rubens. Museo del Prado. Madrid. Cat. 1648.

sumisión a unos designios superiores. La verosimilitud empleada en su ejecución, conduce a que su cuerpo sea enjuto, a que en su cuello los músculos estén en tensión por el poderoso giro que el Santo le imprime a su cabeza y a que en su boca, sobre un prominente mentón, falten los dientes que estructuran esta parte del rostro. Dentro de ese decoro general habría que incluir su piel tostada por el sol tal y como le corresponde a un Apóstol y mártir.

En su mano derecha, completando lo dicho, muestra un pequeño cuchillo, útil con el que fue desollado vivo ${ }^{100}$.

\footnotetext{
100 «Sobre el género de martirio padecido por San Bartolomé existen diferentes versiones... Estas versiones, empero, no son necesariamente contradictorias, sino que, al contrario, todas ellas pueden ser verdaderas, conciliables entre sí y complementarias, puesto que pudo ocurrir que el santo Apóstol fuese primeramente crucificado; luego, antes de morir, descolgado de la cruz y desollado vivo, para hacerle sufrir más; y, finalmente, estando todavía con vida, decapitado». VORAGINE, S. de la: La leyenda dorada..., op. cit., p. 527.
}

"CUADERNOS DE ESTUdIOS GALLEGOS", Tomo XLIII, Fascículo 108, Santiago 1996. 
San Matías ${ }^{101}$. (Láms. 31-32) Este es identificado por el hacha que sostiene en su mano izquierda ${ }^{102}$. La imagen emerge de un fondo oscuro sobre el que se recorta, acusando, tal vez con mayor intensidad que en otros casos, los fuertes contrastes de luz y sombras; la importancia de aquella y su acertado empleo se pone de manifiesto en el destello que surge del filo del hacha haciendo presente y dramático un detalle que, de otro modo, se perdería en la penumbra restándole intensidad emocional a la tabla.

Santo Tomé ${ }^{103}$. (Láms. 33-34) Esta tabla, que se corresponde con el Santiago Alfeo, ratifica la identificación que -desde Beroqui y Madrazo a Norris- se ha hecho de la misma como una representación de Santo Tomás. Dos datos pueden influir en tal asignación, excluyendo, por supuesto, el epígrafe: en primer lugar, el segur o escuadra que lleva en su mano y lo identifica como constructor o arquitecto $^{104}$; en segundo lugar, es el único que aparece con la cabeza cubierta, rasgo que tradicionalmente caracteriza a los artistas.

San Simón ${ }^{105}$. (Láms. 35-36) Lo mismo que ocurría en el caso del Apóstol San Felipe, San Simón es representado como un anciano de larga y abundante barba cana que concentra su atención en el voluminoso libro que está leyendo. La luz, que, desde lo alto, ilumina el rostro y el libro, dota a la imagen de una gran plasticidad y sentido escultórico. Prado.

${ }^{101}$ (S.MATIAS). Se corresponde con el número 1653 del catálogo del Museo del

102 «Dos falsos testigos que declararon contra él fueron los primeros en arrojar algunas piedras sobre su persona; pero el Apóstol las recogió y manifestó su deseo de que aquellos guijarros fuesen enterrados con él... Después de haber sido apedreado, mientras con sus brazos extendidos hacia el cielo encomendaba su espíritu a Dios, acercóse a él un soldado y, conforme a la costumbre romana, con una afilada hacha le cortó su cabeza y puso fin a la vida del Apóstol». VORAGINE, S. de la: La leyenda dorada..., op. cit., p. 184.

${ }^{103}$ (SNTHOME). Se corresponde con el número 1651 del catálogo del Museo del Prado.

${ }^{104}$ En La leyenda dorada se recoge el episodio en el cual el Apóstol para evangelizar la India se presentó a Gondóforo, su rey, como constructor. VORAGINE, S. de la: $L a$ leyenda dorada..., op. cit., pp. 46-52.

${ }^{105}$ (S.SIMON). Se corresponde con el número 1654 del catálogo del Museo del Prado.

"CUADERNOS DE ESTUDIOS GALLEGOS", Tomo XLIII, Fascículo 108, Santiago 1996. 


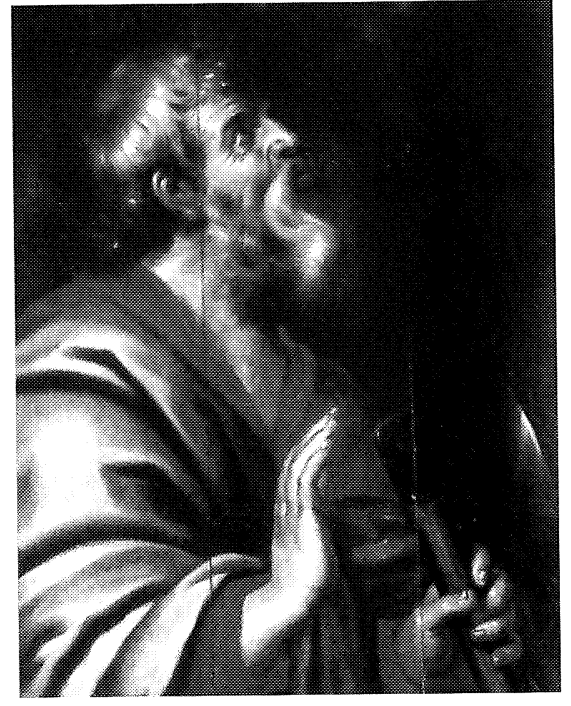

Lámina 31. San Matías. Museo das Mariñas. Betanzos.

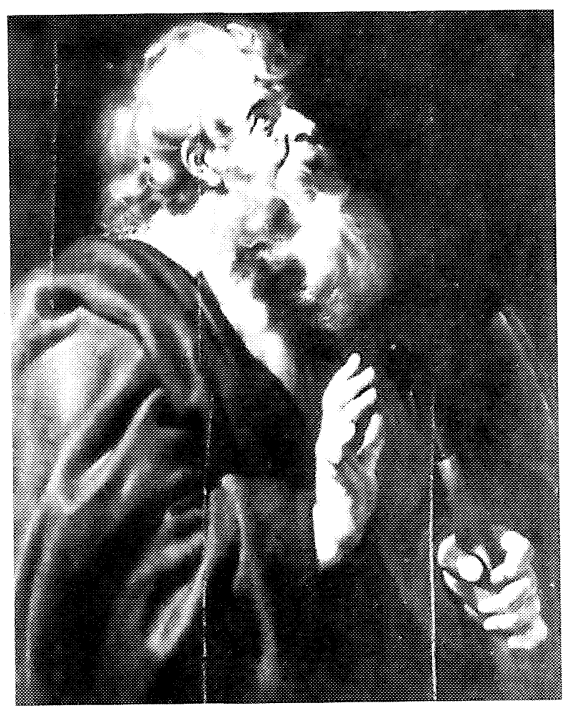

Lámina 32. San Matías. P.P. Rubens. Museo del Prado. Madrid. Cat. 1653.

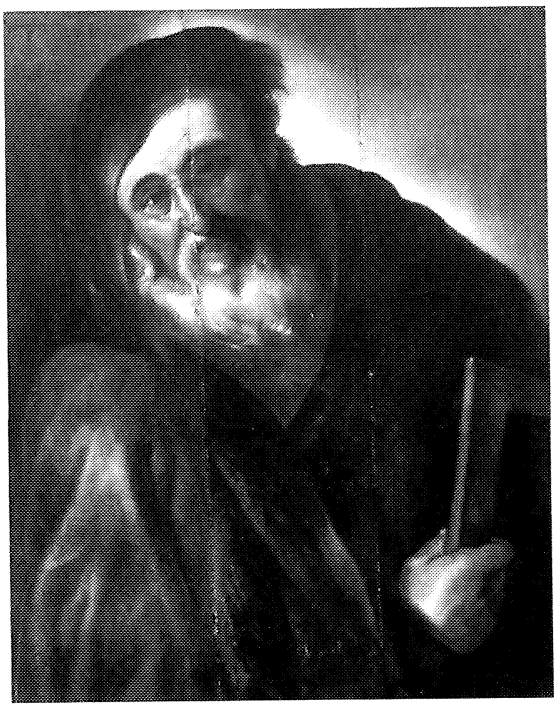

Lámina 33. Santo Tomé. Museo das Mariñas. Betanzos.

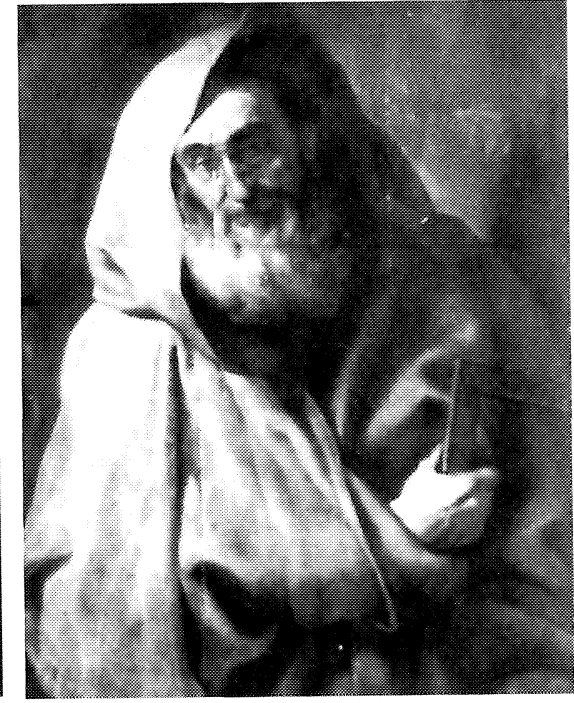

Lámina 34. Santiago el menor. P.P. Rubens. Museo del Prado. Madrid. Ct. 1649 . 


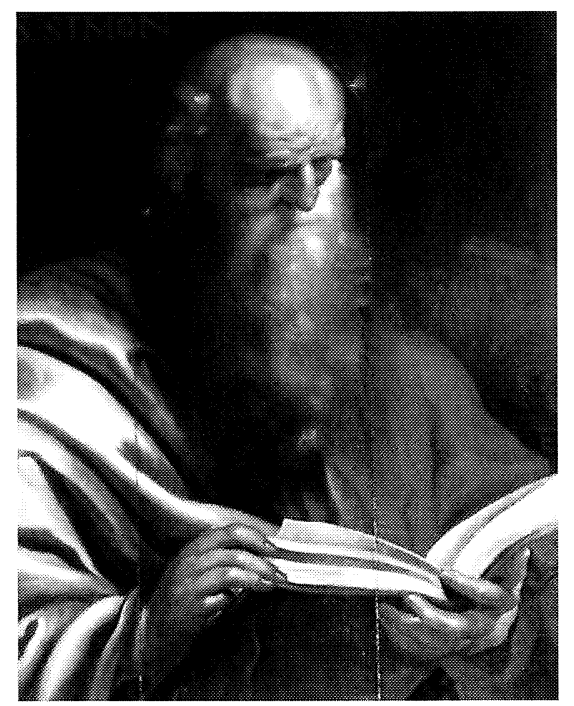

Lámina 35. San Simón. Museo das Mariñas. Betanzos.

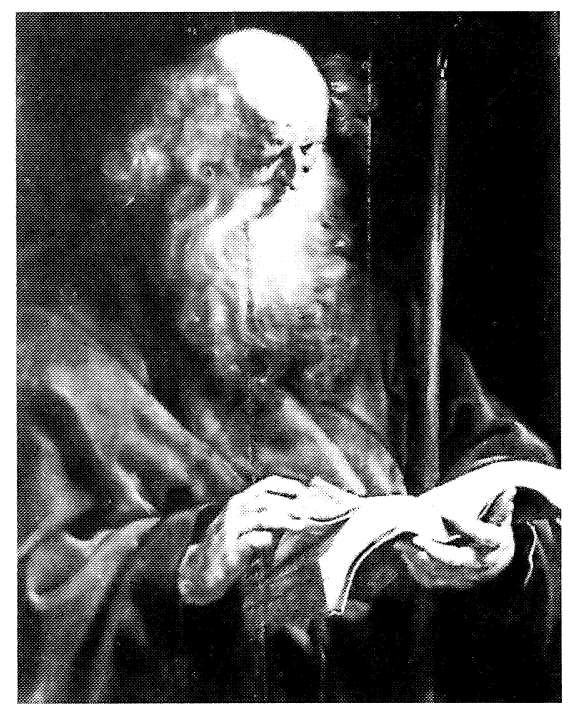

Lámina 36. Santo Tomé. P.P. Rubens. Museo del Prado. Madrid. Cat. 1648.

San Judas Tadeo ${ }^{106}$. (Lám. 37) Este Apóstol, un joven de largos cabellos, imberbe y de tez lechosa, ha estado desde un principio asociado a su hermano Simón, junto al cual predicó y fue martirizado ${ }^{107}$. Su ejecución, en especial la posición de sus manos, repite el mismo esquema utilizado en la tabla de San Pedro, mientras que, su fisionomía de rasgos suaves y, ligeramente afeminados -de carnaciones blandas y nacaradas y de mirada intensa- recuerdan a la de San Juan Evangelista, aunque sin la languidez de éste. Es preciso señalar que esta misma figura, en la serie del Museo del Prado, identificada mayoritariamente como San Mateo, fue considerada por Madrazo y Sánchez Cantón como Judas Tadeo (Catálogo, 1972).

San Pablo ${ }^{108}$. (Láms. 38-39) Se trata de una imagen que, tal vez por semejanza con la de San Pedro, viste una túnica cerrada a la altura del pecho y un amplio manto que le cae por los hombros; en su mano derecha sostiene una gran espada -una montante como la define Ayala ${ }^{109}$ - cuya

${ }^{106}$ (S.JVDAS/THADEO). Se corresponde con el número 1656 del catálogo del Museo del Prado.

${ }^{107}$ VORAGINE, S. de la: La leyenda dorada .., op. cit., pp. 681-687.

${ }^{108}$ (S.PABLO). Se corresponde con el número 1657 del catálogo del Museo del Prado.

${ }^{109}$ INTERIAN DE AYALA, J. Fr.: Pictor Christianus Eruditus..., op. cit., II, 297.

"CUADERNOS DE ESTUDIOS GALLEGOS", Tomo XLIII, Fascículo 108, Santiago 1996. 


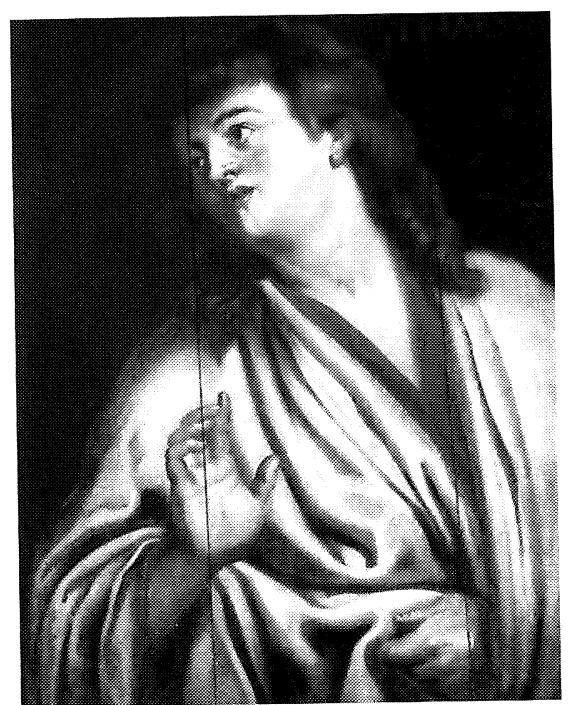

Lámina 37. San Judas Tadeo.

Museo das Mariñas. Betanzos.

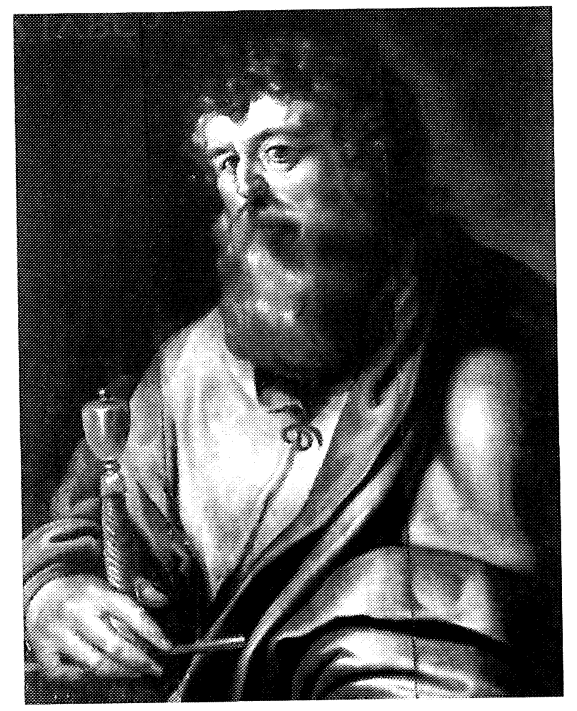

Lámina 38. San Pablo. Museo das Mariñas. Betanzos.

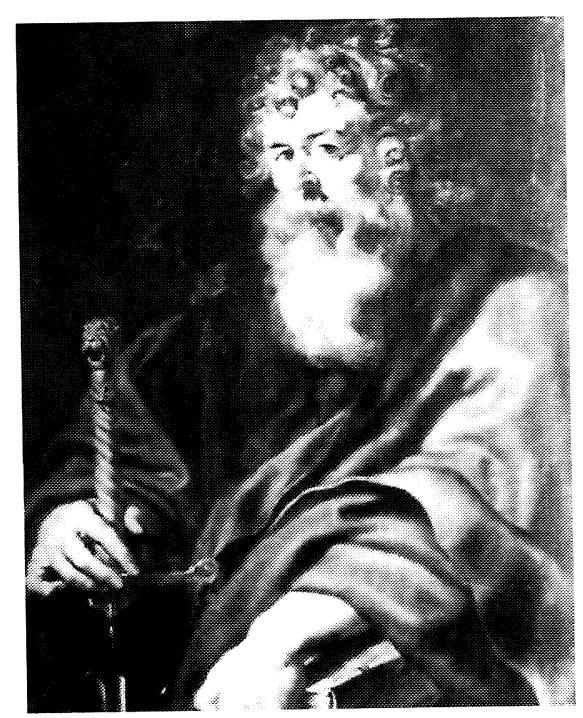

Lámina 39. San Pablo. P.P. Rubens. Museo del Prado. Madrid. Ct. 1649 . 
empuñadura y gavilanes se han simplificado en relación a la existente en la tabla madrileña, mientras que en la izquierda, aunque no se vea, agarraría un libro.

A pesar de que este cuadro conserva gran parte de la energía que irradia el personaje de la obra del Prado, la ausencia de la mano izquierda, cuyos dedos y dorso se tensan en torno al libro, la menor agitación de sus cabellos -transformados ahora en graciosos y ordenados rizos- y su barba recta, le restan fuerza a la imagen. No obstante, su mirada, directa y penetrante, muestra mucha de aquella intensidad.

Salvator Mundi ${ }^{110}$. (Lám. 40) Esta tabla presidiría la serie ya descrita del Hospital de San Antonio de Padua. En ella, Cristo, desnudo, con paño de pureza, abraza el madero de la cruz ${ }^{111}$. El tema le permite al artista realizar un detallado estudio anatómico en el que la luz modela con suaves degradaciones su cuerpo.

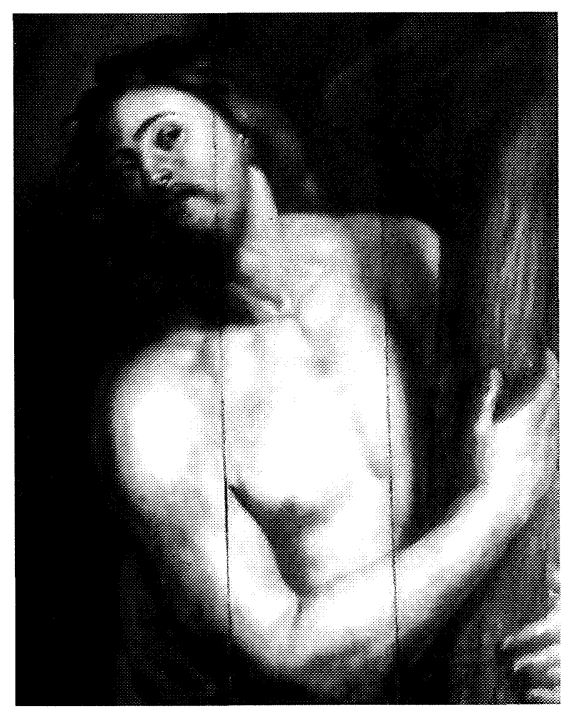

Lámina 40. Salvador Mundi Museo das Mariñas. Betanzos.

\footnotetext{
${ }^{110}$ La serie guardada en el Museo del Prado no cuenta con este cuadro que, sin embargo, se conserva en la Galería Rospiligiossi-Palavicino de Roma y en Otawa. LAFUENTE FERRARI, E.: El Prado..., op. cit., pp. 197

"I La misma composición, aunque de cuerpo entero, aparece en el frontispicio del libro de Iacobo Bosio Crux Triumphans et Gloriosa..., Antuerpiae, ex officina plantiniana, MDCXVII. Cfr. JUDSON, J.R., VELDE, C. van de: Book Illustrations and Title-pages. Brusela, 1978, pp. 183-184, lám. 126.
}

"CUADERnOS DE ESTUdiOS GALLEGOS", Tomo XLIII, Fascículo 108, Santiago 1996. 